\title{
Resuming aspirin in patients with non-variceal upper gastrointestinal bleeding: a systematic review and meta-analysis
}

\author{
Jana G. Hashasha*, Roni Aoun ${ }^{a *}$, Nadim El-Majzoub ${ }^{b}$, Assem Khamisc, Don Rockeyd, Elie A. Aklc, Kassem Barada \\ *Indicates shared first authorship
}

American University of Beirut, Riad El Solh, Beirut, Lebanon; Medical University of South Carolina, USA

\begin{abstract}
Background Our primary and secondary aims were to analyze the evidence surrounding mortality and re-bleeding risks in patients on aspirin with non-variceal upper gastrointestinal bleeding (NVUGIB) as a function of whether or not aspirin was resumed after the bleeding episode, and to determine whether aspirin intake upon admission affected the outcomes.

Methods A search for randomized controlled trials (RCTs) and prospective observational studies was performed. Data extraction and risk of bias assessment were done. Generic inverse variance and random-effects model were employed. Heterogeneity across studies was assessed using the $I^{2}$ test. Certainty of evidence was assessed using the GRADE approach for each comparison and outcome, and an evidence profile was created.

Results Evidence from 1 RCT and 4 observational studies suggests that early aspirin resumption reduced mortality (hazard ratio [HR] 0.20,95\% confidence interval [CI] 0.06-0.63) while increasing re-bleeding risk (HR 1.90, 95\%CI 0.60-6.00); moderate certainty of evidence. The observational evidence was inconsistent for both mortality (HR 0.84, 95\%CI 0.54-1.33) and re-bleeding (HR $0.85,95 \%$ CI $0.47-1.55)$; very low certainty of evidence. Nine observational studies addressed our secondary aim: 6 provided inconsistent results regarding mortality (pooled odds ratio [OR] 1.1, 95\%CI 0.80-1.50) and 4 provided inconsistent results regarding re-bleeding risk (pooled OR 0.92, 95\%CI 0.53-1.59); very low certainty of evidence for both outcomes.
\end{abstract}

Conclusion Evidence supporting a protective effect of aspirin resumption soon after NVUGIB is of low-to-moderate certainty, and is not informative as to the optimal timing of aspirin resumption.

Keywords Aspirin, mortality, re-bleeding, non-variceal upper gastrointestinal bleeding

Ann Gastroenterol 2021; 34 (1): 1-20

\section{Introduction}

Aspirin use increases the risk of gastrointestinal bleeding (GIB) [1-3], but the effects of its use on patients' clinical outcomes

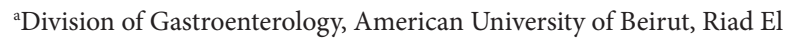
Solh, Beirut, Lebanon (Jana G. Hashash, Roni Aoun, Kassem Barada); ${ }^{\mathrm{b}}$ American University of Beirut, Riad El Solh, Beirut, Lebanon (Nadim El-Majzoub); 'Clinical Research Institute, American University of Beirut, Riad El Solh, Beirut, Lebanon (Assem Khamis, Elie A. Akl); dDivision of Gastroenterology, Medical University of South Carolina, USA (Don Rockey)

Conflict of Interest: None

Correspondence to: Kassem Barada, MD, Professor of Medicine, Division of Gastroenterology, American University of Beirut, Riad El Soloh, 110236 Beirut, Lebanon, e-mail: kb02@aub.edu.lb

Received 8 November 2020; accepted 4 January 2021; published online 23 March 2021

DOI: https://doi.org/10.20524/aog.2021.0617 are uncertain. Many societies have issued recommendations regarding aspirin resumption in patients who develop GIB whilst on this drug. Some recommend that in patients using aspirin who develop non-variceal upper GIB (NVUGIB), aspirin resumption should be assessed [4]. Others recommend that aspirin should be discontinued in the majority of patients who are taking it for primary cardiovascular prevention, given the minimal cardiovascular benefit [4-7], while patients with cardiovascular disease (CVD) should resume it soon after the bleeding stops [4,7], because failure to do so may increase mortality risk $[4,8]$. One randomized controlled trial (RCT) showed that patients with CVD who resumed low-dose aspirin after achieving endoscopic hemostasis for NVUGIB had potentially reduced mortality rates up to 2 months from the bleeding event, but may have an increased risk of re-bleeding [8].

No studies have identified the safest timing for resuming aspirin. The Asia-Pacific working group recommended that "among patients with high cardio-thrombotic risk receiving antiplatelet agents, these agents should be resumed as soon as hemostasis can be established" [9]. They recommend resumption 
of antiplatelet agents on day 1 if endoscopy shows a clean based ulcer, and waiting $72 \mathrm{~h}$ in patients who receive endoscopic therapy for control of NVUGIB [9]. European guidelines recommend holding aspirin until day 3 after endoscopic control of high-risk lesions [10]. Furthermore, American guidelines conditionally recommend the resumption of aspirin in patients with CVD, stating that "aspirin should be resumed as soon as possible after bleeding ceases in most patients: ideally within 1-3 days and certainly within 7 days" [4], or holding a discussion with the patient's cardiologist if a patient with NVUGIB is receiving antiplatelet therapy [11]. Finally, a joint consensus statement from Cardiology and Gastroenterology organizations recommends resuming antiplatelet therapy 3-7 days after bleeding cessation in patients with CVD [6].

A major limitation of the current guidelines is that they are based on a limited number of studies involving a small number of patients who experienced a small number of events. In addition, there was substantial variability in the duration of follow up, timing of aspirin resumption, and the time point from which events were included in the analyses. Finally, some studies included only patients with severe bleeding who required endoscopic therapy, while others included all-comers with NVUGIB.

The primary aim of our study was to synthesize the evidence for all-cause mortality and re-bleeding with resuming vs. not resuming aspirin amongst patients admitted with NVUGIB. A secondary aim was to determine whether being on aspirin at the time of admission for NVUGIB is associated with better or worse outcomes compared to not being on aspirin.

\section{Materials and methods}

We designed and conducted this systematic review following the Cochrane methodology [12] and we report it following the PRISMA guidelines as demonstrated on the PRISMA checklist (Appendix 1). We registered the protocol in the International Prospective Register of Systematic Reviews (PROSPERO), with registration number: CRD42016037461 (Fig. 1).

\section{Eligibility criteria}

\section{Study design}

RCTs, prospective studies, and retrospective studies with prospective follow up were included. Full texts and abstracts in any language were included. For the secondary aim, only fulltext articles written in languages familiar to reviewers (English or French) were included. There was no language restriction for articles addressing the primary aim.

\section{Participants}

Patients admitted with NVUGIB (study reported separate data for an NVUGIB subgroup, or NVUGIB patients accounted for $\geq 90 \%$ of cases).

\section{Comparison groups}

For the primary aim, the intervention was defined as resuming aspirin following NVUGIB (separate data for aspirin subgroup, or $\geq 80 \%$ of patients were on aspirin). The control group was defined as not resuming aspirin. For the secondary aim, exposure was defined as having been on aspirin prior to NVUGIB, while the non-exposed group was defined as not having been on it.

\section{Outcomes}

The primary outcome was all-cause mortality, while the secondary outcome was re-bleeding. We accepted the authors' definition of re-bleeding.

\section{Search methods for identification of studies}

We searched MEDLINE Ovid (January 1946-September 2018), PubMed, EMBASE Ovid (January 1974-September 2018), Cochrane database of systematic reviews and Web of Science. Appendix 2 lists our search strategies. We also searched OpenGrey, MedNar, Proquest Dissertation and Theses open; and clinical trials registries: Clinicaltrials.gov, International Standard Randomized Controlled Trial Number, Register EU Clinical Trials Register, International Clinical Trial Registry Platform. We screened the reference lists of included studies and other relevant publications. We used no language restrictions.

\section{Study selection}

Two teams of 2 reviewers each (RA and JGH, and NEM and $\mathrm{KB}$ ) selected studies for inclusion in duplicate and independently (titles and abstract screening followed by full text screening). Reviewers compared the results of full text screening and resolved discrepancies by discussion, or with the help of a third reviewer. We used a standardized full text screening form and all reviewers participated in calibration exercises.

\section{Data collection}

The 2 teams abstracted data from eligible studies in duplicate and independently and resolved disagreements by discussion, or with the help of a third reviewer. A standardized pilot tested form was used and reviewers participated in calibration exercises.

For the primary aim, we documented clinical characteristics, definition of NVUGIB, indication for aspirin use (primary or secondary prevention), use of other anticoagulants or antiplatelet agents, as well as relevant statistical data. Data regarding aspirin resumption, including its timing after 


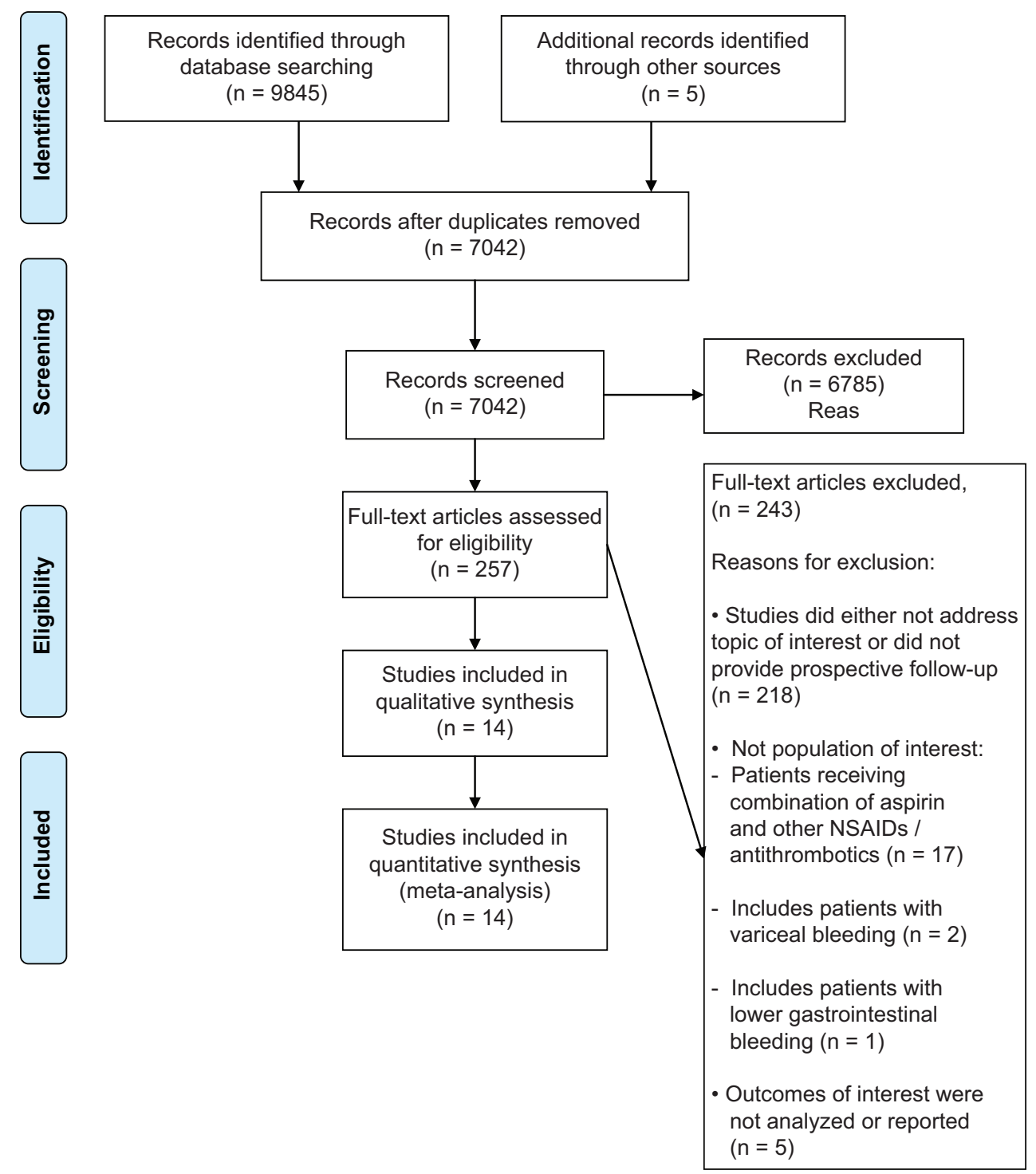

Figure 1 PRISMA 2009 flow diagram

NSAIDs, nonsteroidal anti-inflammatory drugs

NVUGIB, dose, and use of concomitant anticoagulants or antiplatelets, was also gathered. The follow-up period for each outcome, including all-cause mortality and cause-specific mortality, was recorded. When available, a definition for rebleeding was recorded.

\section{Assessment of risk of bias (RoB)}

The RoB of RCTs was assessed using the Cochrane tool in duplicate and independently, and disagreements were resolved by discussion. For observational studies, methodological criteria included the development and application of appropriate eligibility criteria, measurement of exposure, measurement of outcome, controlling for confounders, and completeness of data as proposed by the GRADE working group [13].

\section{Data synthesis}

We extracted the hazard ratio (HR) effect estimates for mortality and re-bleeding when reported by the study. HR is a relative measure of an effect of an intervention on an outcome of interest over time and does not inform about the absolute risk. An HR of 1 means a lack of association, while an HR greater than 1 suggests an increased risk and an HR less than 1 suggests a smaller risk. In our manuscript, an HR greater than 1 suggested an increased risk of mortality or re-bleeding. Otherwise, we calculated the relative risk (RR) using the number of events. The log of the effect estimates (HR and RR) was pooled using a generic inverse variance method and a random-effects model in Review Manager 5. Heterogeneity across studies was assessed using the $I^{2}$ test and considered substantial if $I^{2}$ was $>50 \%$. Inverted funnel plots were created to check for possible publication bias. Certainty of evidence at the outcome level was assessed using the GRADE approach 
for each comparison and outcome, and an evidence profile summarizing that assessment was created.

\section{Subgroup analysis}

We determined whether the relative effect of aspirin resumption on mortality was modified by whether aspirin was used for primary or secondary prevention, and by whether follow up was for more or less than 6 months from NVUGIB admission.

\section{Results}

\section{Selection process}

The initial bibliographic search identified 9845 citations. Fig. 1 shows the PRISMA flow diagram and details of the study selection. We identified 14 eligible studies: 13 observational [14-26] and 1 RCT [8]. Four observational studies $[16,17,21,26]$ and the single RCT [8] addressed our primary aim. Nine observational studies addressed our secondary aim [14,15,18-20,22-25].

\section{Primary aim: resuming vs. not resuming aspirin}

Appendix 3 provides detailed information regarding the characteristics of the included studies and the RoB assessment.

\section{Characteristics of studies}

Five studies addressed our primary aim, 4 retrospective with prospective follow up $[16,17,21,26]$, and 1 RCT [8]. Three were conducted in single centers $[8,16,26]$, while 2 were multicenter $[17,21]$. Observational studies provided a prospective follow up for 2953 patients on aspirin prior to admission, while the RCT provided follow up for 156 patients. Two studies $[8,16]$ exclusively included patients with peptic ulcer bleeding (PUB), while one [21] exclusively included patients with non-valvular atrial fibrillation. Timing of aspirin resumption varied from 24 $\mathrm{h}$ following endoscopic intervention to up to 60 days following the bleeding episode. Timing was not specified in 1 study [21].

Follow-up time varied from 8 weeks to 5 years. All 5 studies addressed mortality. All except for Gonzalez-Perez et al addressed re-bleeding rates [17]. Re-bleeding required endoscopic verification in 2 studies $[8,16]$.

\section{RoB assessment for observational studies}

RoB for development and application of appropriate eligibility criteria was considered low for all studies except one [21], where patients could have been taking antithrombotics other than aspirin. In all 4 observational studies $[16,17,21,26]$, the assessment of aspirin use was based solely on trusted medical databases. We considered the RoB for measurement of exposure to be unclear for all studies, as patients could have been prescribed aspirin and not taken it. Aspirin is available over the counter, and could have been taken without prescription.

RoB for assessment of outcomes was considered low for all studies addressing mortality except for one [17], and for all those addressing re-bleeding except for one [16], where it was not clear how these outcomes were assessed. Controlling for important confounders was established in 2 studies [16,21] and RoB was deemed high in the other two $[17,26]$. There was no mention of missing data in any of the 4 studies. RoB for data completeness was therefore considered unclear.

\section{RoB assessment for the RCT}

There was a low risk for potential bias in the RCT (Appendix 3) [8].

\section{Effects of aspirin resumption on mortality}

In the RCT [8], HR for mortality in patients who resumed aspirin compared to those who did not was 0.20 (95\%CI 0.060.63 ; Fig. 2A), with moderate certainty of evidence, rated down due to imprecision (Table 1 ).

A meta-analysis of 4 observational studies $[16,17,21,26]$ for mortality generated a pooled HR of 0.84 (95\%CI 0.54 $1.33 ; I^{2}=67 \%$ ) in patients who resumed aspirin after NVUGIB compared to those who did not (Fig. 2B), with very low certainty of evidence due to inconsistency and imprecision (Table 1).

A meta-analysis of 4 observational studies $[16,17,21,26]$ and the RCT [8] combined for mortality in patients who resumed aspirin compared to those who did not generated a pooled HR of 0.69 (95\%CI $0.42-1.15 ; I^{2}=72 \%$ ), with very low certainty of evidence, rated down due to the RoB in observational studies as well as imprecision and inconsistency (Table 1).

A subgroup analysis was performed to determine whether the relative effect of aspirin resumption on mortality might be modified by whether patients were taking aspirin for primary or secondary prevention. When considering studies with less than 6 months of follow up after resumption of aspirin, a meta-analysis of 3 studies $[8,16,17]$ where aspirin was used for secondary prevention revealed a pooled HR of 0.35 (95\%CI $0.09-1.29 ; I^{2}=78 \%$ ) for mortality in patients who resumed aspirin compared to those who did not (Fig. 3A). Certainty of evidence was judged very low. On the other hand, one observational study [17] where aspirin was used for primary prevention found a HR of 4.07 (95\%CI 0.54-30.74) for mortality in patients who resumed aspirin compared to those who discontinued it (Fig. 3A). Certainty of evidence was deemed very low. The $\mathrm{P}$-value of the test for the subgroup effect was 0.05 .

In studies where follow up was for more than 6 months after aspirin resumption, a meta-analysis of 2 studies [16,21] where aspirin was used for secondary prevention found a pooled HR of $0.80\left(95 \%\right.$ CI $\left.0.56-1.15 ; I^{2}=16 \%\right)$ for mortality in patients 


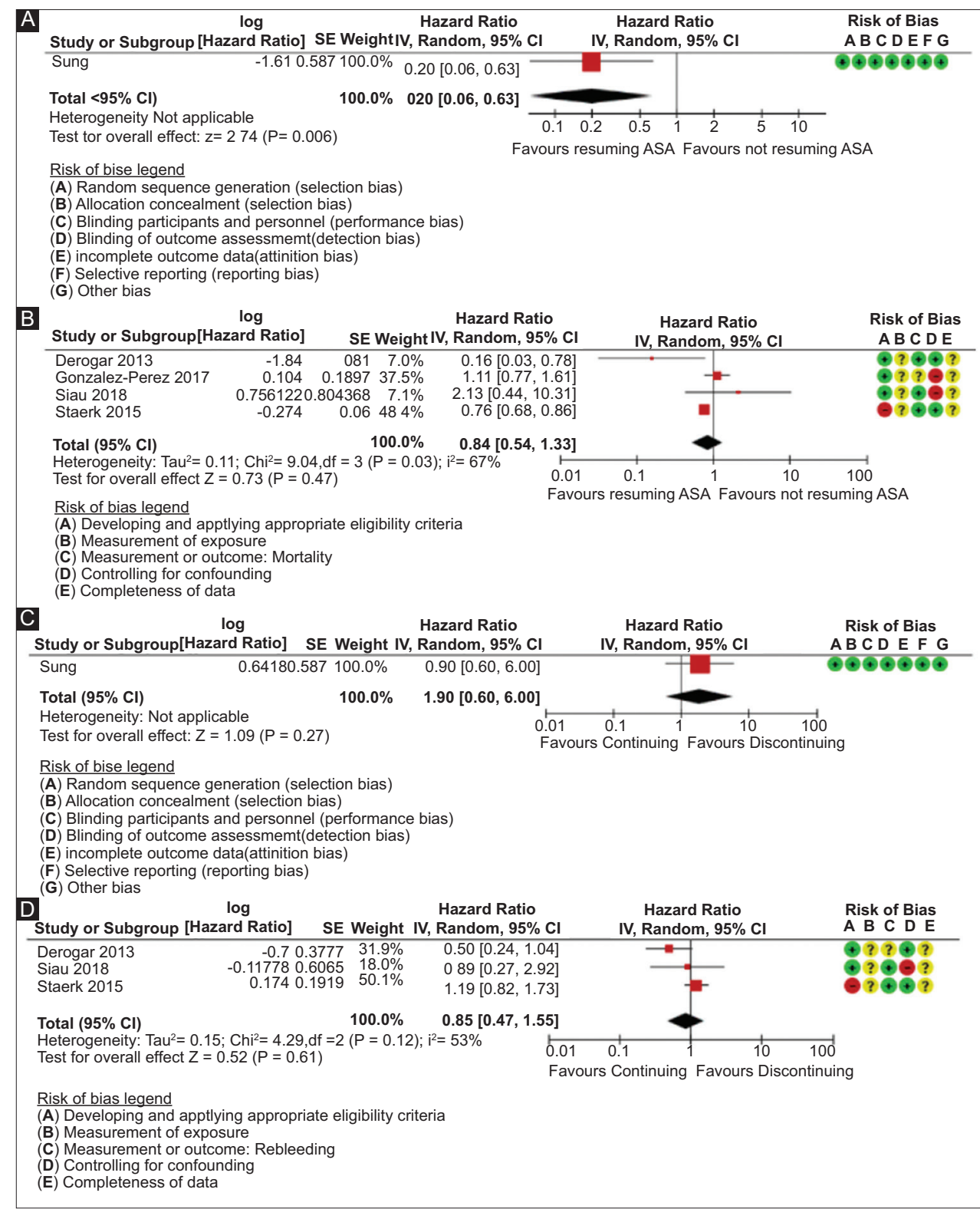

Figure 2 Effects of aspirin resumption on mortality in patients with non-variceal upper gastrointestinal bleeding (NVUGIB); (A) randomized controlled trial (RCT); (B) observational studies; and effects of aspirin resumption on re-bleeding in patients with NVUGIB; (C) RCT; (D) observational studies

CI, confidence interval

who resumed aspirin compared to those who discontinued it (Fig. 3B). However, one observational study [16] where aspirin was used for primary prevention found an HR of 0.56 (95\%CI 0.08-3.82) for mortality in patients who resumed aspirin compared to those who discontinued it (Fig. 3B). Certainty of evidence was very low. The P-value of the test for the subgroup effect was 0.71 .

\section{Effects of aspirin resumption on re-bleeding}

The RCT [8] did not exclude an increase in the risk of rebleeding in patients who resumed aspirin compared to those who did not (Fig. 2C), with moderate certainty of evidence, rated down due to very serious imprecision (Table 1).

A meta-analysis of 3 observational studies [16,21,26] generated a pooled $\mathrm{HR}$ for re-bleeding in patients who resumed aspirin compared to those who discontinued it of 0.85 (95\%CI $0.47-1.55 ; I^{2}=53 \%$; Fig. $2 \mathrm{D}$ ), with very low certainty of evidence, rated down due to imprecision and inconsistency (Table 1).

A meta-analysis of 3 observational studies and the RCT $[8,16,21,26]$ combined found a pooled HR for the effect of aspirin resumption on re-bleeding of 0.97 (95\%CI 0.58-1.64; $I^{2}=45 \%$ ), with very low certainty of evidence, rated down due to imprecision. 


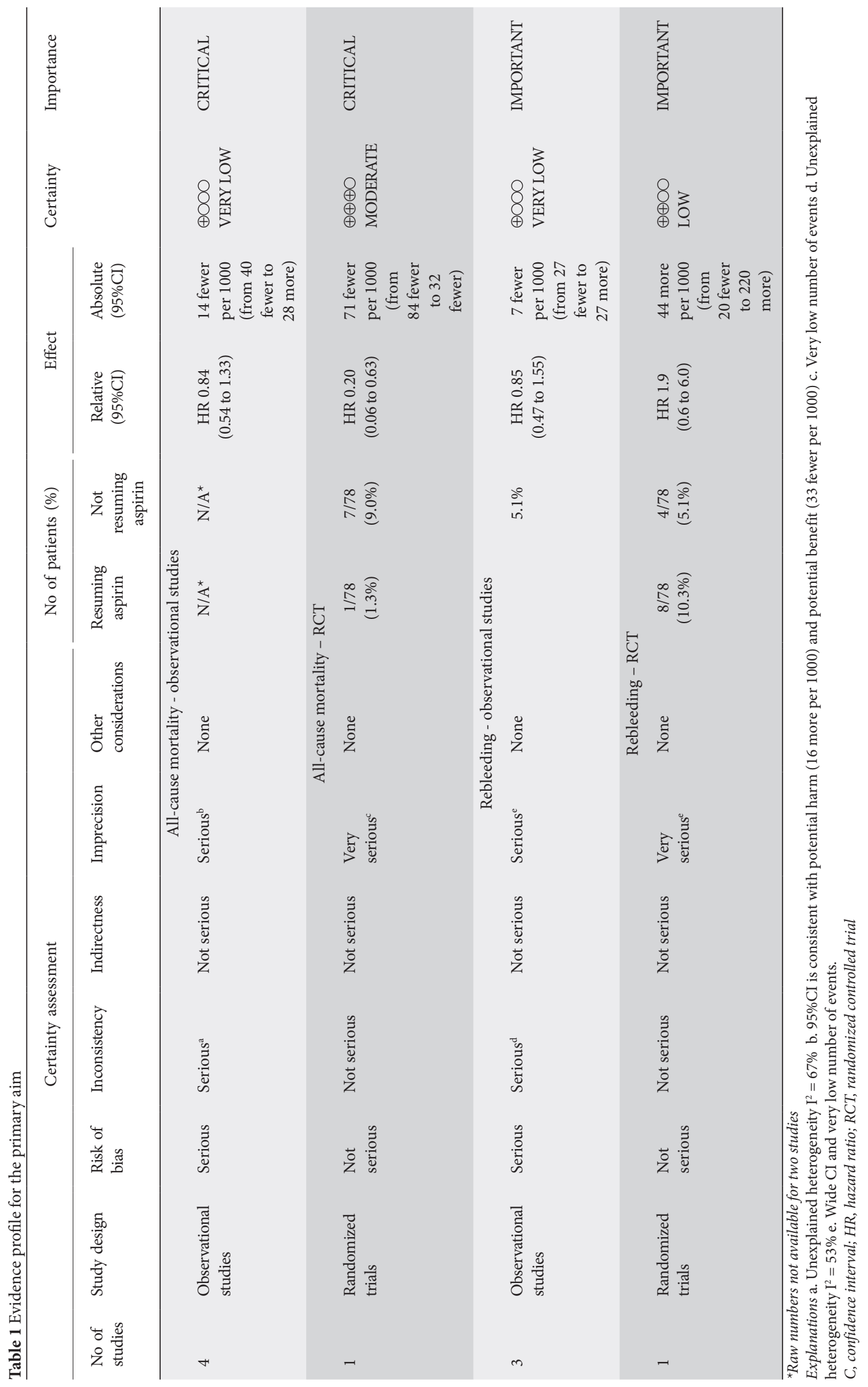




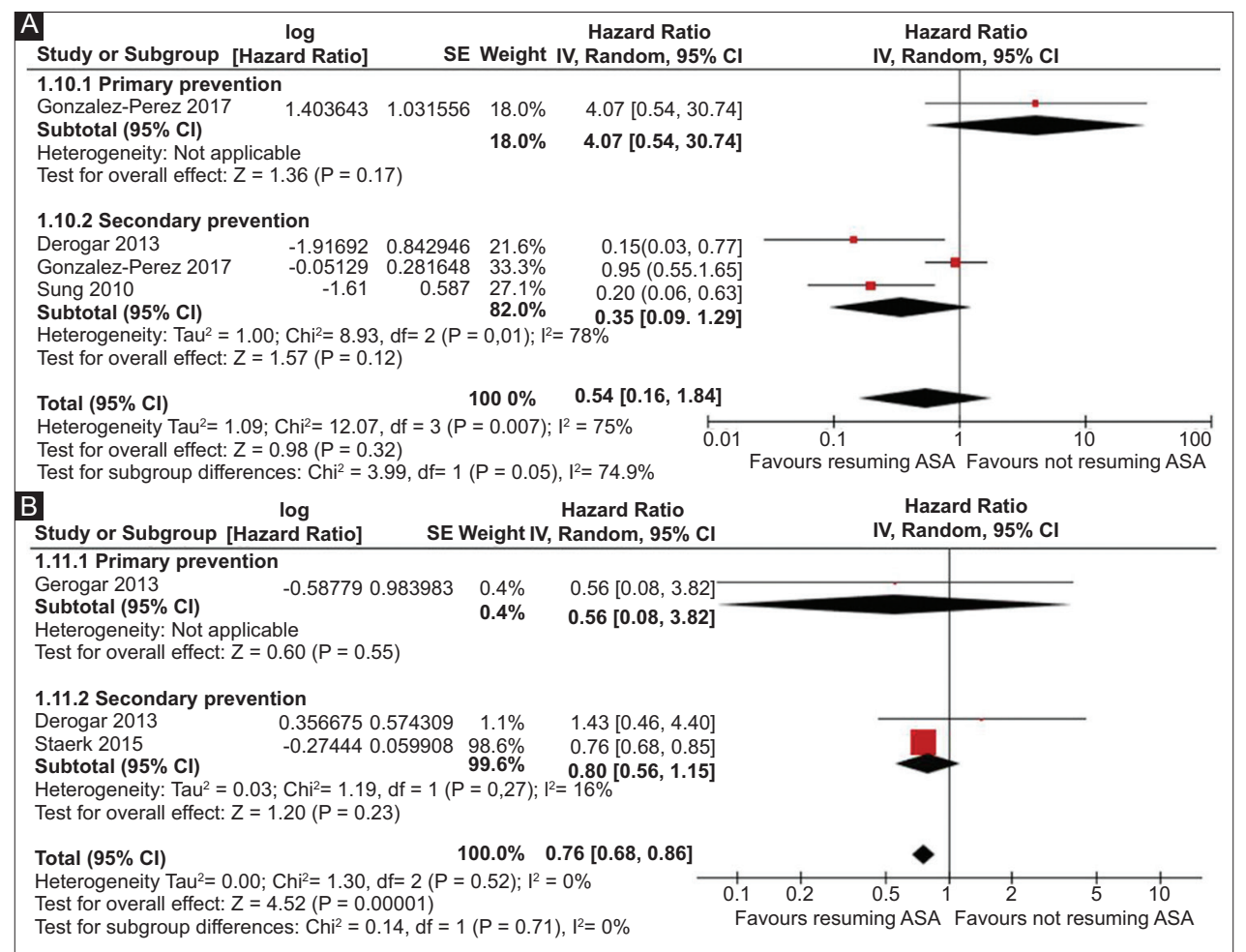

Figure 3 Effects of aspirin resumption on mortality in patients with non-variceal upper gastrointestinal bleeding (NVUGIB) stratified by whether it was used for primary or secondary prevention; (A) mortality within 6 months following NVUGIB; (B) mortality after more than 6 months following NVUGIB

CI, confidence interval

\section{Secondary aim: being on aspirin vs. not being on aspirin at time of admission for NVUGIB}

Appendix 3 provides detailed information regarding the characteristics of included studies as well as the RoB assessment.

Characteristics of included studies

Nine studies addressed our secondary question [14,15,18-20,22-25]. Among those, 1 was an RCT [25], 6 were prospective observational studies $[14,15,18,19,22,23]$, and 2 were retrospective with prospective follow up [20,24]. These studies provided follow up for 14,762 patients. All studies but one included only patients with PUB [23].

Whether aspirin was used for primary vs. secondary prevention was not mentioned in any of the studies. Follow-up time varied from "in-hospital" to up to 10 years. Data regarding mortality was available from 7 studies [14,15,19,20,22-24], while data regarding re-bleeding was available from 6 studies [14,18,20,22,23,25].

\section{RoB assessment}

RoB for development and application of appropriate eligibility criteria was considered low for all studies, except for Liang 2016, where no specific diagnostic criteria for rebleeding were mentioned [20].

RoB for measurement of exposure was considered low for 5 studies $[14,15,18-20]$, as data regarding aspirin use prior to NVUGIB were retrieved from trusted resources. In 4 studies [22-25], it was unclear how data regarding aspirin intake were retrieved. RoB for measurement of mortality and re-bleeding for all 9 studies was low [14,15,18-20,22-25].

Controlling for confounders was not established in 5 studies $[15,19,22,24,25]$ and hence their RoB was deemed high. In 3 studies [14,20,23], it was unclear whether patients were taking other antithrombotics, thus the RoB was considered to be unclear. Controlling for all confounders was well established in one study [18]. There was no mention of missing data in any of the studies (unclear risk) except for Camus et al, where the risk was low [14].

\section{Association of aspirin use prior to NVUGIB with mortality}

A meta-analysis of 6 studies $[15,19,20,22-24]$ generated a pooled odds ratio (OR) of 1.1 (95\%CI $0.80-1.5 ; I^{2}=42 \%$ ) for mortality in patients who were on aspirin prior to NVUGIB compared to those who were not (Fig. 4), with very low certainty of evidence due to imprecision.

\section{Effect of aspirin use prior to NVUGIB on re-bleeding}

A meta-analysis of 4 observational studies [14,18,20,25] generated a pooled OR of $0.92\left(95 \%\right.$ CI $\left.0.53-1.59 ; I^{2}=80 \%\right)$ for re-bleeding in patients who were on aspirin prior to NVUGIB 
compared to those who were not (Fig. 5), with very low certainty of evidence due to imprecision and heterogeneity (Supplementary Table 1).

\section{Discussion}

This is the first systematic review to examine the effect of aspirin resumption on mortality and re-bleeding and evaluate the association between being on aspirin and clinical outcomes in patients with NVUGIB. We found that starting aspirin after NVUGIB may be associated with lower mortality, although the evidence supporting this conclusion is weak $[8,16,17,21,26]$. No study compared different timings of aspirin resumption. We observed variability in the indications for aspirin use, duration of follow up, and time point from which follow up began (Appendix 3). Furthermore, an increased risk of re-bleeding cannot be excluded with early aspirin resumption. Re-bleeding is common after initial NVUGIB [27] and is a predictor of mortality. Most re-bleeding episodes occur within a month of the initial event [8] and the risk continues to increase with time [21]. Evidence concerning the effects of resuming aspirin on re-bleeding is less conclusive than that concerning mortality, because of the small number of patients and re-bleeding events $[8,16]$. Drawing firm conclusions about the benefits of early aspirin resumption is complicated by observations that this is associated with reduced mortality not only from thrombotic events, but also from non-cardiovascular causes [8]. Additionally, many patients on aspirin are also taking other antithrombotics and it is difficult to ascertain the outcomes related to aspirin alone. In the secondary aim, we evaluated the effect of being on aspirin on mortality and re-bleeding, as there were prospective and retrospective studies suggesting that it confers a protective effect $[23,28]$. This might inform risk stratification and prognostication in patients with NVUGIB. We were unable to confirm a decrease or increase in the odds of mortality or re-bleeding in patients on aspirin [14,15,18-20,22-25]. There was considerable clinical heterogeneity among studies. Moreover, it was unclear whether patients on aspirin were on other antithrombotics. Finally, the duration of follow up was 30 days in most, but not in all studies. Our results are therefore based on a small number of studies that are clinically heterogeneous and hence the evidence is of very low certainty.

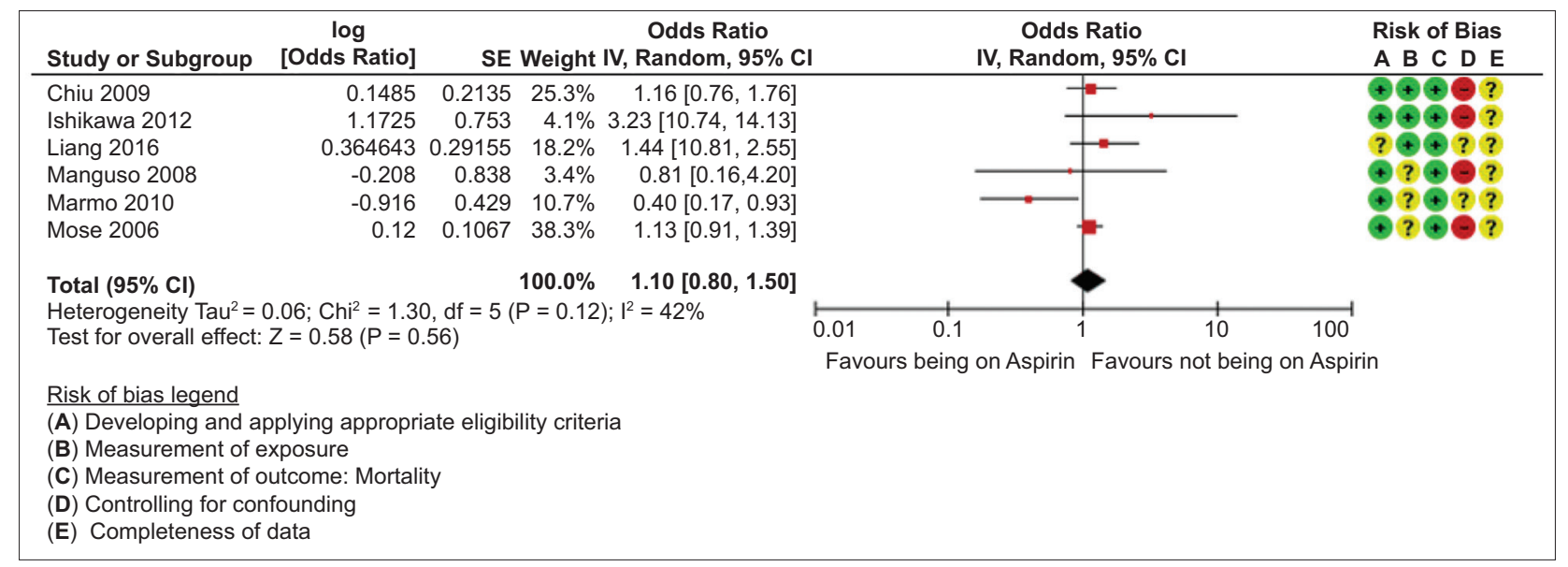

Figure 4 Effects of aspirin use prior to non-variceal upper gastrointestinal bleeding on mortality CI, confidence interval

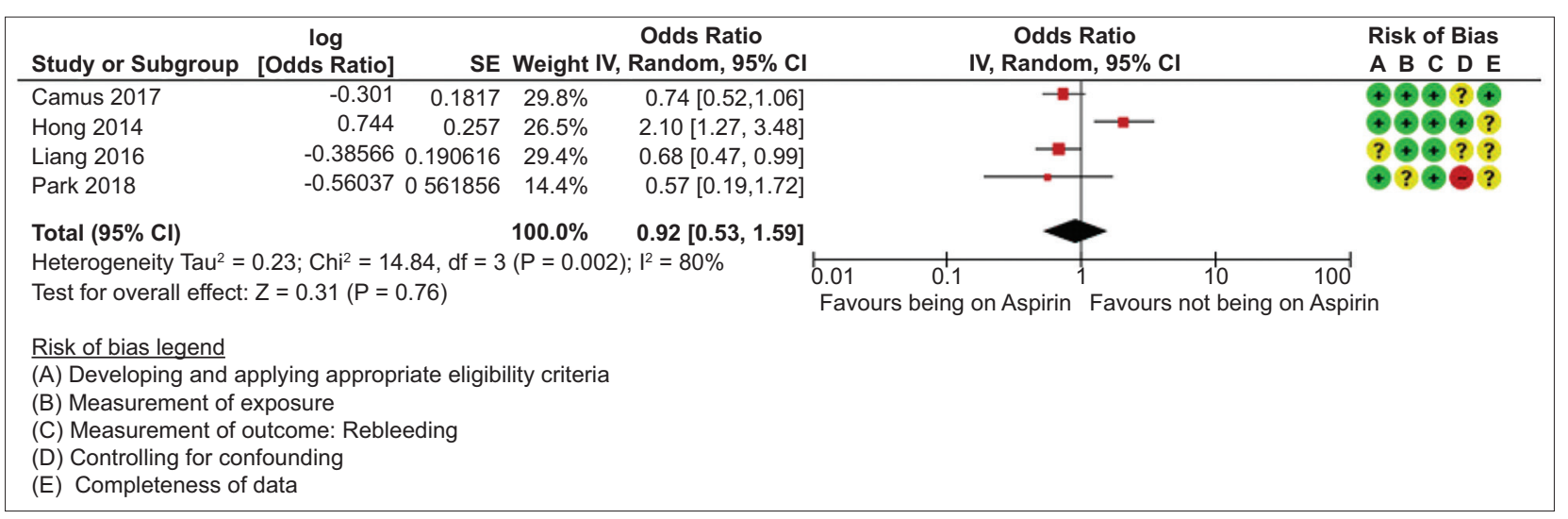

Figure 5 Effects of aspirin use prior to non-variceal upper gastrointestinal bleeding on re-bleeding CI, confidence interval 
Limitations of this meta-analysis include limitations in the methodology and the data analyzed, due to the poor quality of the majority of studies and the high levels of clinical and statistical heterogeneity. In that regard, current guidelines are based on limited data and/or expert opinion.

For patients taking aspirin for primary prophylaxis, our meta-analysis lends support to guidelines recommending stopping it after NVUGIB, although the evidence for that is weak. For patients taking aspirin for secondary prophylaxis, this review lends some support to resuming it once hemostasis is established, as this may be associated with reduced mortality, but may increase the risk of re-bleeding. Evidence supporting this recommendation is weak to moderate. Most thrombotic events start to occur about 8 days after aspirin is discontinued, and rebleeding events occur within the first 5 days in those who resume it [29]. An RCT is needed comparing resumption of aspirin vs. interruption of aspirin for 1 week in patients who require aspirin for secondary prevention. This RCT would compare the risk of re-bleeding in a homogeneous group of patients with highrisk stigmata who resume aspirin vs. those who do not. Timedependent events would be expected to provide evidence on the best timing for aspirin resumption. Many questions remain unanswered. Whether aspirin should be discontinued at all in NVUGIB patients who are taking it for secondary prevention is unclear. Additionally, the exact timing for aspirin resumption remains unknown, and it remains challenging to balance the risks of thromboembolic events and re-bleeding.

\section{Summary Box}

\section{What is already known:}

- Aspirin use increases the risk of gastrointestinal bleeding, but its effects on patients' clinical outcomes are uncertain

- After non-variceal upper gastrointestinal bleeding, aspirin should not be resumed in patients taking it for primary prevention

- After non-variceal upper gastrointestinal bleeding, aspirin should be resumed in patients taking it for secondary prevention

\section{What the new findings are:}

- Evidence supporting a protective effect of aspirin resumption soon after non-variceal upper gastrointestinal bleeding is of low-to-moderate certainty

- The available evidence is not informative as to the optimal timing of aspirin resumption

\section{References}

1. Malfertheiner P, Chan FK, McColl KE. Peptic ulcer disease. Lancet 2009;374:1449-1461.
2. Feinstein LB, Holman RC, Yorita Christensen KL, Steiner CA, Swerdlow DL. Trends in hospitalizations for peptic ulcer disease, United States, 1998-2005. Emerg Infect Dis 2010;16:1410-1418.

3. Hernández-Díaz S, García Rodríguez LA. Cardioprotective aspirin users and their excess risk of upper gastrointestinal complications. BMC Med 2006;4:22.

4. Laine L, Jensen DM. Management of patients with ulcer bleeding. Am J Gastroenterol 2012;107:345-360.

5. Baigent C, Blackwell L, Collins R, et al; Antithrombotic Trialists' (ATT) Collaboration. Aspirin in the primary and secondary prevention of vascular disease: collaborative meta-analysis of individual participant data from randomised trials. Lancet 2009;373:1849-1860.

6. Abraham NS, Hlatky MA, Antman EM, et al; ACCF/ACG/AHA. ACCF/ACG/AHA 2010 expert consensus document on the concomitant use of proton pump inhibitors and thienopyridines: a focused update of the ACCF/ACG/AHA 2008 expert consensus document on reducing the gastrointestinal risks of antiplatelet therapy and NSAID use. Am J Gastroenterol 2010;105:2533-2549.

7. Oakland K, Chadwick G, East JE, et al. Diagnosis and management of acute lower gastrointestinal bleeding: guidelines from the British Society of Gastroenterology. Gut 2019;68:776-789.

8. Sung JJ, Lau JY, Ching JY, et al. Continuation of low-dose aspirin therapy in peptic ulcer bleeding: a randomized trial. Ann Intern Med 2010;152:1-9.

9. Sung JJ, Chiu PW, Chan FKL, et al. Asia-Pacific working group consensus on non-variceal upper gastrointestinal bleeding: an update 2018. Gut 2018;67:1757-1768.

10. Gralnek IM, Dumonceau JM, Kuipers EJ, et al. Diagnosis and management of nonvariceal upper gastrointestinal hemorrhage: European Society of Gastrointestinal Endoscopy (ESGE) Guideline. Endoscopy 2015;47:a1-a46.

11. Acosta RD, Abraham NS, Chandrasekhara V, et al; ASGE Standards of Practice Committee. The management of antithrombotic agents for patients undergoing GI endoscopy. Gastrointest Endosc 2016;83:3-16.

12. Higgins JPT, Green S (editors). Cochrane Handbook for Systematic Reviews of Interventions Version 5.1.0 [updated March 2011]. The Cochrane Collaboration, 2011. Available from: http://handbook. cochrane.org [Accessed 22 February 2021].

13. Guyatt GH, Oxman AD, Vist G, et al. GRADE guidelines: 4. Rating the quality of evidence-study limitations (risk of bias). J Clin Epidemiol 2011;64:407-415.

14. Camus M, Jensen DM, Kovacs TO, Jensen ME, Markovic D, Gornbein J. Independent risk factors of 30-day outcomes in 1264 patients with peptic ulcer bleeding in the USA: large ulcers do worse. Aliment Pharmacol Ther 2016;43:1080-1089.

15. Chiu PW, Ng EK, Cheung FK, et al. Predicting mortality in patients with bleeding peptic ulcers after therapeutic endoscopy. Clin Gastroenterol Hepatol 2009;7:311-316.

16. Derogar M, Sandblom G, Lundell L, et al. Discontinuation of lowdose aspirin therapy after peptic ulcer bleeding increases risk of death and acute cardiovascular events. Clin Gastroenterol Hepatol 2013;11:38-42.

17. González-Pérez A, Sáez ME, Johansson S, Nagy P, García Rodríguez LA. Mortality in patients who discontinue low-dose acetylsalicylic acid therapy after upper gastrointestinal bleeding. Pharmacoepidemiol Drug Saf 2017;26:215-222.

18. Hong MJ, Lee SY, Kim JH, et al. Rebleeding after initial endoscopic hemostasis in peptic ulcer disease. J Korean Med Sci 2014;29:1411-1415.

19. Ishikawa S, Inaba T, Mizuno M, et al. Characteristics of serious complicated gastroduodenal ulcers in Japan. Hepatogastroenterology 2012;59:147-154.

20. Liang CM, Hsu CN, Tai WC, et al. Risk factors influencing the outcome of peptic ulcer bleeding in chronic kidney disease after 
initial endoscopic hemostasis. A nationwide cohort study. Medicine (Baltimore) 2016;95:e4795.

21. Staerk L, Lip GY, Olesen JB, et al. Stroke and recurrent haemorrhage associated with antithrombotic treatment after gastrointestinal bleeding in patients with atrial fibrillation: nationwide cohort study. BMJ 2015;351:h5876.

22. Manguso F, Riccio E, Bennato R, et al. In-hospital mortality in non-variceal upper gastrointestinal bleeding Forrest 1 patients. Scand J Gastroenterol 2008;43:1432-1441.

23. Marmo R, Koch M, Cipolletta L, et al; Italian registry on upper gastrointestinal bleeding (Progetto Nazionale Emorragie Digestive-PNED 2). Predicting mortality in non-variceal upper gastrointestinal bleeders: validation of the Italian PNED Score and prospective comparison with the Rockall Score. Am J Gastroenterol 2010;105:1284-1291.

24. Mose H, Larsen M, Riis A, et al. Thirty-day mortality after peptic ulcer bleeding in hospitalized patients receiving low-dose aspirin at time of admission. Am J Geriatr Pharmacother 2006;4:244-250.

25. Park SJ, Park H, Lee YC, et al. Effect of scheduled second-look endoscopy on peptic ulcer bleeding: a prospective randomized multicenter trial. Gastrointest Endosc 2018;87:457-465.

26. Siau K, Hannah JL, Hodson J, Widlak M, Bhala N, Iqbal TH. Stopping antithrombotic therapy after acute upper gastrointestinal bleeding is associated with reduced survival. Postgrad Med J 2018;94:137-142.

27. Wong GL, Wong VW, Chan Y, et al. High incidence of mortality and recurrent bleeding in patients with Helicobacter pylori-negative idiopathic bleeding ulcers. Gastroenterology 2009;137:525-531.

28. Wehbeh A, Tamim HM, Abu Daya H, et al. Aspirin has a protective effect against adverse outcomes in patients with nonvariceal upper gastrointestinal bleeding. Dig Dis Sci 2015;60:2077-2087.

29. Lanas A, Dumonceau JM, Hunt RH, et al. Non-variceal upper gastrointestinal bleeding. Nat Rev Dis Primers 2018;4:18020. 


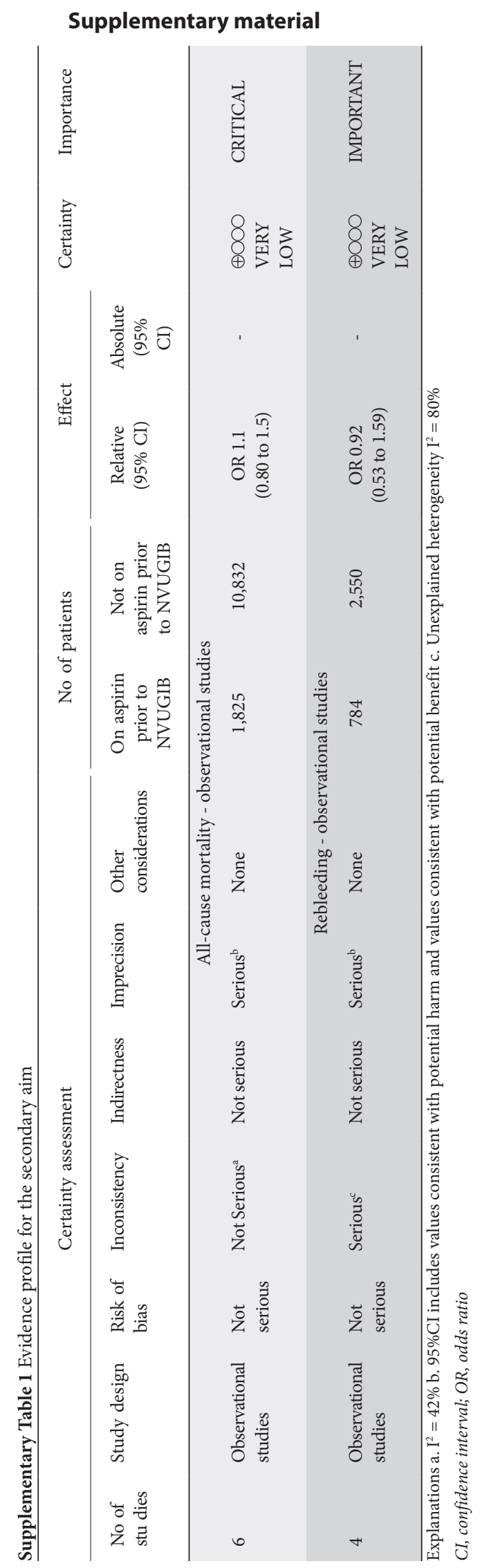




\begin{tabular}{|c|c|c|c|}
\hline Section/topic & \# & Checklist item & Reported on page \# \\
\hline \multicolumn{4}{|c|}{ TITLE } \\
\hline Title & 1 & Identify the report as a systematic review, meta-analysis, or both & 1 \\
\hline \multicolumn{4}{|c|}{ ABSTRACT } \\
\hline Structured summary & 2 & $\begin{array}{l}\text { Provide a structured summary including, as applicable: background; } \\
\text { objectives; data } \\
\text { sources; study eligibility criteria, participants, and interventions; } \\
\text { study appraisal and } \\
\text { synthesis methods; results; limitations; conclusions and implications } \\
\text { of key findings; } \\
\text { systematic review registration number }\end{array}$ & 3 \\
\hline \multicolumn{4}{|c|}{ INTRODUCTION } \\
\hline Rationale & 3 & $\begin{array}{l}\text { Describe the rationale for the review in the context of what is already } \\
\text { known }\end{array}$ & $5-6$ \\
\hline Objectives & 4 & $\begin{array}{l}\text { Provide an explicit statement of questions being addressed with } \\
\text { reference to participants, interventions, comparisons, outcomes, and } \\
\text { study design (PICOS) }\end{array}$ & 6 \\
\hline \multicolumn{4}{|c|}{ METHODS } \\
\hline Protocol and registration & 5 & $\begin{array}{l}\text { Indicate if a review protocol exists, if and where it can be } \\
\text { accessed (e.g., Web address), and, if available, provide registration } \\
\text { information including registration number }\end{array}$ & 6 \\
\hline Eligibility criteria & 6 & $\begin{array}{l}\text { Specify study characteristics (e.g., PICOS, length of follow up) and } \\
\text { report characteristics (e.g., years considered, language, publication } \\
\text { status) used as criteria for eligibility, giving rationale }\end{array}$ & 7 \\
\hline Information sources & 7 & $\begin{array}{l}\text { Describe all information sources (e.g., databases with dates of } \\
\text { coverage, contact with study authors to identify additional studies) in } \\
\text { the search and date last searched }\end{array}$ & $7-8$ \\
\hline Search & 8 & $\begin{array}{l}\text { Present full electronic search strategy for at least one database, } \\
\text { including any limits used, such that it could be repeated }\end{array}$ & $7-8$ \\
\hline Study selection & 9 & $\begin{array}{l}\text { State the process for selecting studies (i.e., screening, eligibility, } \\
\text { included in systematic review, and, if applicable, included in the } \\
\text { meta-analysis) }\end{array}$ & $8-9$ \\
\hline Data collection process & 10 & $\begin{array}{l}\text { Describe method of data extraction from reports (e.g., piloted forms, } \\
\text { independently, in duplicate) and any processes for obtaining and } \\
\text { confirming data from investigators }\end{array}$ & $8-9$ \\
\hline Data items & 11 & $\begin{array}{l}\text { List and define all variables for which data were sought (e.g., PICOS, } \\
\text { funding sources) and any assumptions and simplifications made }\end{array}$ & $8-9$ \\
\hline Risk of bias in individual studies & 12 & $\begin{array}{l}\text { Describe methods used for assessing risk of bias of individual } \\
\text { studies (including Specification of whether this was done at the study } \\
\text { or outcome level), and how this information is to be used in any data } \\
\text { synthesis }\end{array}$ & 9 \\
\hline Summary measures & 13 & $\begin{array}{l}\text { State the principal summary measures (e.g., risk ratio, difference in } \\
\text { means) }\end{array}$ & 9 \\
\hline Synthesis of results & 14 & $\begin{array}{l}\text { Describe the methods of handling data and combining results of } \\
\text { studies, if done, including measures of consistency }\left(\text { e.g., } I^{2}\right) \text { for each } \\
\text { meta-analysis }\end{array}$ & 9 \\
\hline Risk of bias across studies & 15 & $\begin{array}{l}\text { Specify any assessment of risk of bias that may affect the cumulative } \\
\text { evidence (e.g., publication bias, selective reporting within studies) }\end{array}$ & 9 \\
\hline Additional analyses & 16 & $\begin{array}{l}\text { Describe methods of additional analyses (e.g., sensitivity or } \\
\text { subgroup analyses, meta-regression), if done, indicating which were } \\
\text { pre-specified }\end{array}$ & 10 \\
\hline
\end{tabular}




\begin{tabular}{|c|c|c|c|}
\hline Section/topic & $\#$ & Checklist item & Reported on page \# \\
\hline \multicolumn{4}{|c|}{ RESULTS } \\
\hline Study selection & 17 & $\begin{array}{l}\text { Give numbers of studies screened, assessed for eligibility, and included in the } \\
\text { review, with reasons for exclusions at each stage, ideally with a flow diagram }\end{array}$ & 10 \\
\hline Study characteristics & 18 & $\begin{array}{l}\text { For each study, present characteristics for which data were extracted (e.g., } \\
\text { study size, PICOS, follow-up period) and provide the citations }\end{array}$ & $\begin{array}{c}10-11 \\
14\end{array}$ \\
\hline Risk of bias within studies & 19 & $\begin{array}{l}\text { Present data on risk of bias of each study and, if available, any outcome level } \\
\text { assessment (see item 12) }\end{array}$ & $\begin{array}{l}11-12 \\
14-15\end{array}$ \\
\hline Results of individual studies & 20 & $\begin{array}{l}\text { For all outcomes considered (benefits or harms), present, for each study: (a) } \\
\text { simple summary data for each intervention group (b) effect estimates and } \\
\text { confidence intervals, ideally with a forest plot }\end{array}$ & $\begin{array}{l}11-12 \\
14-15\end{array}$ \\
\hline Synthesis of results & 21 & $\begin{array}{l}\text { Present results of each meta-analysis done, including confidence intervals } \\
\text { and measures of consistency }\end{array}$ & $\begin{array}{c}12-14 \\
15\end{array}$ \\
\hline Risk of bias across studies & 22 & Present results of any assessment of risk of bias across studies (see Item 15) & $\begin{array}{l}11-12 \\
14-15\end{array}$ \\
\hline Additional analysis & 23 & $\begin{array}{l}\text { Give results of additional analyses, if done (e.g., sensitivity or subgroup } \\
\text { analyses, meta-regression [see Item 16]) }\end{array}$ & $12-13$ \\
\hline \multicolumn{4}{|c|}{ DISCUSSION } \\
\hline Summary of evidence & 24 & $\begin{array}{l}\text { Summarize the main findings including the strength of evidence for each } \\
\text { main outcome; consider their relevance to key groups (e.g., healthcare } \\
\text { providers, users, and policy makers) }\end{array}$ & 16 \\
\hline Limitations & 25 & $\begin{array}{l}\text { Discuss limitations at study and outcome level (e.g., risk of bias), and at } \\
\text { review-level (e.g., incomplete retrieval of identified research, reporting bias) }\end{array}$ & 17 \\
\hline Conclusions & 26 & $\begin{array}{l}\text { Provide a general interpretation of the results in the context of other } \\
\text { evidence, and implications for future research }\end{array}$ & 17 \\
\hline \multicolumn{4}{|c|}{ FUNDING } \\
\hline Funding & 27 & $\begin{array}{l}\text { Describe sources of funding for the systematic review and other support } \\
\text { (e.g., supply of data); role of funders for the systematic review }\end{array}$ & 2 \\
\hline
\end{tabular}

From: Moher D, Liberati A, Tetzlaff J, Altman DG, The PRISMA Group. Preferred Reporting Items for Systematic Reviews and Meta-Analyses: The PRISMA Statement. PLoS Med 2009;6:e1000097 


\section{Appendix 2 Search strategy}

\section{Search strategy for Medline (Via Ovid)}

1. exp Aspirin/ (39695)

2. (Aspirin ${ }^{\star}$ or dispril or polopiryna or zorprin or (acetylsalicylic adj acid) or polopirin or colfarit or aloxiprimum or micristin or easprin or magnecyl or solprin or ecotrin or (2- acetyloxy benzoic adj acid) or endosprin or acylpyrin or solupsan or acetysal $\left.{ }^{\star}\right)$.ti,ab,sh.

3. 1 or 2

4. exp Upper Gastrointestinal Tract/

5. ((upper adj2 (gi or alimentar ${ }^{*}$ or digestiv $^{*}$ or intestin ${ }^{*}$ or enteral ${ }^{*}$ or enteric $\left.c^{\star}\right)$ ) or ugi or stomac $c^{\star}$ or (upper adj2 gastro $^{*}$ ) or gastri ${ }^{*}$ or epigastr ${ }^{\star}$ or oesopha* or esopha* or duoden ${ }^{\star}$ or peptic ${ }^{\star}$ or antrum ${ }^{*}$ or antral ${ }^{\star}$ or pylor ${ }^{\star}$ or nonvaric or $^{\star}$ (non adj varic $\left.c^{\star}\right)$ ).ti,ab,sh.

6. 4 or 5

7. exp Hemorrhage/

8. (hemorrhag* or hemorhag* or rehemorhag* or rehemorrhag* or re-hemorhag* or re- hemorrhag* ${ }^{*}$ or haemorrhag* or haemorhag* or rehaemorrhag* or re-haemorrhag* ${ }^{\star}$ or rehaemorhag ${ }^{\star}$ or bleed $^{\star}$ or re-bleed ${ }^{\star}$ or rebleed $\left.{ }^{\star}\right)$.ti,ab,sh.

9. 7 or 8

10. 6 and 9

11. (melena $^{*}$ or melaena ${ }^{*}$ or hematem ${ }^{*}$ or haematem ${ }^{*}$ or coffee or hematochez $z^{*}$ or haematochez $z^{*}$ or gastrorrha ${ }^{*}$ or gastrorha ${ }^{*}$ or (Mallory adj Weis ${ }^{\star}$ ) or Dieulafo* ${ }^{*}$ or NVGIB or NVUGIB).ti,ab,sh.

12. exp Peptic Ulcer Hemorrhage/ or exp Mallory-Weiss Syndrome/

13. exp Gastrointestinal Hemorrhage/

14. 13 and (4 or 5$)$

15. 10 or 11 or 12 or 14

16. 3 and 15

17. 16 not (animals/ not (animals/ and humans/))

\section{Search strategy for PubMed}

1. Aspirin

2. Aspirin ${ }^{\star}[\mathrm{tw}]$ OR dispril[tw] OR polopiryna[tw] OR zorprin[tw] OR acetylsalicylic $\operatorname{acid}^{*}[\mathrm{tw}]$ OR polopirin[tw] OR colfarit[tw] OR aloxiprimum[tw] OR micristin[tw] OR easprin[tw] OR magnecyl[tw] OR solprin[tw] OR ecotrin[tw] OR 2-acetyloxy benzoic $\operatorname{acid}^{*}[\mathrm{tw}]$ OR endosprin[tw] OR acylpyrin[tw] OR solupsan $[\mathrm{tw}]$ OR acetysal ${ }^{\star}[\mathrm{tw}]$ OR acetylsalicylate $\mathrm{H}^{\star}[\mathrm{tw}]$

3. $\# 1 \mathrm{OR} \# 2$

4. Upper Gastrointestinal Tract

5. upper $g^{*}[\mathrm{tw}]$ OR ugi[tw] OR upper $\operatorname{digestiv}^{*}[\mathrm{tw}]$ OR upper alimentar ${ }^{\star}[\mathrm{tw}]$ OR $\operatorname{stomac}^{\star}[\mathrm{tw}]$ OR gastri ${ }^{\star}[\mathrm{tw}]$ OR upper gastroi $i^{*}[\mathrm{tw}]$ OR upper gastro- $\mathrm{i}^{*}[\mathrm{tw}]$ OR gastrod ${ }^{*}[\mathrm{tw}]$ OR gastro$\mathrm{d}^{\star}[\mathrm{tw}]$ OR upper gastroe* $[\mathrm{tw}]$ OR upper gastro- $\mathrm{e}^{\star}[\mathrm{tw}]$ OR epigastr ${ }^{\star}[\mathrm{tw}]$ OR oesopha* $[\mathrm{tw}]$ OR esopha ${ }^{*}[\mathrm{tw}]$ OR duoden ${ }^{*}[\mathrm{tw}]$ OR upper intestin ${ }^{*}[\mathrm{tw}]$ OR upper enteral ${ }^{*}[\mathrm{tw}]$ OR upper enteric ${ }^{\star}[\mathrm{tw}]$ OR peptic ${ }^{\star}[\mathrm{tw}]$ OR antrum ${ }^{\star}[\mathrm{tw}]$ OR antral ${ }^{\star}[\mathrm{tw}]$ OR pylor $^{\star}[\mathrm{tw}]$ OR nonvaric ${ }^{\star}[\mathrm{tw}]$ OR non-varic ${ }^{\star}[\mathrm{tw}]$

6. \#4 OR \#5

7. Hemorrhage

8. hemorrhag* $[\mathrm{tw}]$ OR hemorhag* $\left.{ }^{*} \mathrm{tw}\right]$ OR haemorrhag* $\left.{ }^{*} \mathrm{tw}\right]$ OR haemorhag* $\left.{ }^{*} \mathrm{tw}\right]$ OR rehemorrhag* ${ }^{\star}[\mathrm{tw}]$ OR re-hemorrhag* ${ }^{\star}[\mathrm{tw}]$ OR rehaemorrhag* $[\mathrm{tw}]$ OR re- haemorrhag ${ }^{*}[\mathrm{tw}]$ OR bleed ${ }^{*}[\mathrm{tw}]$ OR rebleed ${ }^{*}[\mathrm{tw}]$ OR re-bleed ${ }^{*}[\mathrm{tw}]$

9. \#7 OR\#8

10. \#6 AND \#9

11. melena ${ }^{*}[\mathrm{tw}]$ OR melaena $\mathrm{O}^{*}[\mathrm{tw}]$ OR hematem ${ }^{*}[\mathrm{tw}]$ OR haematem ${ }^{*}[\mathrm{tw}]$ OR coffee[tw] OR hematoche $z^{*}[\mathrm{tw}]$ OR haematoche $z^{*}[\mathrm{tw}]$ OR gastrorrha* $[\mathrm{tw}]$ OR gastrorha ${ }^{*}[\mathrm{tw}]$
OR Mallory weis ${ }^{*}[\mathrm{tw}]$ OR Dieulafo ${ }^{*}[\mathrm{tw}]$ OR NVGIB[tw] OR NVUGIB[tw]

12. Peptic Ulcer Hemorrhage OR Mallory-Weiss Syndrome

13. Gastrointestinal Hemorrhage

14. \#13 AND (\#4 OR \#5)

15. \#10 OR \#11 OR \#12 OR \#14

16. \#3 AND \#15

17. \#16 NOT ("animals" [MESH] NOT ("animals" [MESH] AND "humans"[MESH]))

\section{Search strategy for Embase (Ovid)}

1. exp acetylsalicylic acid/

2. (aspirin* or (acetylsalicylic adj acid) or acetylsalicylate* or dispril or aloxiprimum or easprin or solprin or polopirin or polopiryna or zorprin or colfarit or micristin or magnecyl or ecotrin or acetyloxybenz $^{\star}$ or endosprin or acylpyrin or solupsan or acetysal). ti,ab,sh.

3. 1 or 2

4. exp upper gastrointestinal tract/

5. (( (upper adj (gi or gastro $)$ ) or ugi or stomac or gastri $^{\star}$ or oesopha ${ }^{\star}$ or esopha ${ }^{\star}$ or duoden ${ }^{\star}$ or peptic ${ }^{\star}$ or nonvaric ${ }^{\star}$ or (non adj varic $\left.{ }^{\star}\right)$ ) adj2 (hemorrhag* ${ }^{\star}$ or hemorhag ${ }^{\star}$ or rehemorhag ${ }^{\star}$ or rehemorrhag ${ }^{\star}$ or re-hemorhag* or re-hemorrhag* or haemorrhag* or haemorhag* or rehaemorrhag ${ }^{*}$ or re-haemorrhag* ${ }^{*}$ rehaemorhag ${ }^{\star}$ or bleed ${ }^{\star}$ or re- bleed ${ }^{*}$ or rebleed $\left.{ }^{\star}\right)$ ).ti,ab,sh.

6. (melena ${ }^{\star}$ or melaena ${ }^{*}$ or hematem ${ }^{*}$ or haematem ${ }^{\star}$ or hematochez ${ }^{\star}$ or haematochez ${ }^{\star}$ or gastrorrha ${ }^{\star}$ or gastrorha ${ }^{\star}$ or NVGIB).ti,ab,sh.

7. exp hematemesis/

8. exp Peptic Ulcer Hemorrhage/

9. gastrointestinal hemorrhage/ or intestinal bleeding/ or small intestine hemorrhage/

10. exp duodenum bleeding/ or exp melena/ or exp peptic ulcer bleeding/or exp stomach hemorrhage/ or exp upper gastrointestinal bleeding/

11. 9 and (4 or upper.mp.) [mp=title, abstract, heading word, drug trade name, original title, device manufacturer, drug manufacturer, device trade name, keyword]

12. 5 or 6 or 7 or 8 or 10 or 11

13.3 and 12

14. 13 not ((exp animal/ or nonhuman/) not exp human/)

\section{Search strategy for Cochrane Database of Systematic Reviews}

1. MeSH descriptor: [Aspirin] explode all trees

2. Aspirin ${ }^{\star}$ or dispril or polopiryna or zorprin or (acetylsalicylic next acid) or polopirin or colfarit or aloxiprimum or micristin or easprin or magnecyl or solprin or ecotrin or (2- acetyloxy benzoic next acid) or endosprin or acylpyrin or solupsan or acetysal:ti,ab,kw

3. \#1 or \#2

4. MeSH descriptor: [Upper Gastrointestinal Tract] explode all trees

5. ((upper near/2 (gi or alimentar ${ }^{\star}$ or digestiv ${ }^{\star}$ or intestin ${ }^{\star}$ or enteral ${ }^{\star}$ or enteric $\left.{ }^{\star}\right)$ ) or ugi or stomac $c^{\star}$ or (upper near/2 gastro ${ }^{\star}$ ) or gastri ${ }^{\star}$ or epigastr ${ }^{\star}$ or oesopha* or esopha* or duoden ${ }^{\star}$ or peptic* or antrum ${ }^{\star}$ or antral ${ }^{\star}$ or pylor ${ }^{\star}$ or nonvaric ${ }^{\star}$ or (non next varic $\left.\left.{ }^{\star}\right)\right): \mathrm{ti}, \mathrm{ab}, \mathrm{kw}$

6. \#4 or \#5

7. MeSH descriptor: [Hemorrhage] explode all trees

8. hemorrhag* ${ }^{*}$ or hemorhag* ${ }^{*}$ or rehemorhag ${ }^{*}$ or rehemorrhag ${ }^{*}$ or rehemorhag* or (re- hemorrhag ${ }^{\star}$ ) or haemorrhag ${ }^{\star}$ or haemorhag ${ }^{\star}$ or rehaemorrhag* ${ }^{\star}$ or re-haemorrhag* ${ }^{\star}$ or rehaemorhag* ${ }^{*}$ bleed ${ }^{\star}$ or $\left(\right.$ re-bleed $\left.^{\star}\right)$ or rebleed ${ }^{\star}:$ ti,ab,kw 
9. $\# 7$ or $\# 8$

10. $\# 6$ and $\# 9$

11. melena* ${ }^{*}$ melaena ${ }^{*}$ or hematem ${ }^{*}$ or haematem ${ }^{*}$ or coffee or hematoche $z^{\star}$ or haematoche $z^{\star}$ or gastrorrha* ${ }^{*}$ or gastrorha* or (mallory next weis ${ }^{\star}$ ) or Dieulafo ${ }^{\star}$ or NVGIB or NVUGIB:ti,ab,kw

12. MeSH descriptor: [Gastrointestinal Hemorrhage] explode all trees

13. MeSH descriptor: [Mallory-Weiss Syndrome] explode all trees

14. \#12 and \#6

15. \#10 or \#11 or \#13 or \#14

16. \#3 and \#15

\section{Search strategy for Web of Science}

1. $\left(\left(\left(\left(\left(\right.\right.\right.\right.\right.$ Aspirin ${ }^{\star}$ OR dispril OR polopiryna OR zorprin OR polopirin OR colfarit OR aloxiprimum OR micristin OR easprin OR magnecyl OR solprin OR ecotrin OR endosprin OR acylpyrin OR solupsan OR acetysal $\left.\left.\left.\left.^{*}\right)\right)\right)\right)$ )

2. ((acetylsalicylic NEAR/1 acid))

3. (("2-acetyloxy benzoic" NEAR/1 acid))

4. \#3 OR \#2 OR \#1

5. ((((c"Upper Gastrointestinal Tract” OR ugi OR stomac ${ }^{\star}$ OR gastri ${ }^{\star}$ OR epigastr ${ }^{\star}$ OR oesopha* OR esopha* OR duoden ${ }^{\star}$ OR peptic ${ }^{\star}$ OR antrum ${ }^{\star}$ OR antral ${ }^{\star}$ OR pylor ${ }^{\star}$ OR nonvaric $\left.\left.\left.\left.{ }^{\star}\right)\right)\right)\right)$ )

6. ((upper NEAR/1 (gi OR alimentar* OR digestiv ${ }^{\star}$ OR intestin $^{\star} \mathrm{OR}$ enteral ${ }^{\star} \mathrm{OR}$ enteric $\left.\left.{ }^{\star}\right)\right)$ )

7. ((upper NEAR/2 gastro $\left.{ }^{\star}\right)$ )

8. ((non NEAR/1 varic $\left.\left.^{\star}\right)\right)$

9. \#8 OR \#7 OR \#6 OR \#5
10. ((((hemorrhag* ${ }^{*}$ OR hemorhag* OR rehemorhag* OR rehemorrhag* OR re-hemorhag* OR re-hemorrhag* OR haemorrhag* OR haemorhag* OR rehaemorrhag* OR rehaemorrhag* OR rehaemorhag* OR bleed ${ }^{\star}$ OR re-bleed ${ }^{\star}$ OR rebleed $\left.\left.\left.\left.^{*}\right)\right)\right)\right)$

11. \#10 AND \#9

12. $\left(\left(\left(\right.\right.\right.$ melena $^{*}$ OR melaena ${ }^{*}$ OR hematem ${ }^{*}$ OR haematem ${ }^{\star}$ OR coffee OR hematochez ${ }^{\star}$ OR haematochez ${ }^{\star}$ OR gastrorrha ${ }^{\star}$ OR gastrorha $^{\star}$ ) OR Dieulafo* OR NVGIB OR NVUGIB)))

13. (Mallory NEAR/1 Weis*)

14. \#13 OR \#12

15. \#14 OR \#11

16. \#15 AND \#4

Search strategy for ProQuest, OpenGrey, Mednar, Clincal Trials, ISRCTN, EU-CTR

(aspirin OR acetylsalicylates OR acetylsalicylic) AND (((upper gastrointestinal OR stomach OR esophageal OR duodenal OR peptic OR nonvariceal) AND (Bleeding OR bleed OR rebleed OR hemorrhage OR rehemorrhage)) OR (melena OR hematemesis OR hematochezia OR NVGIB OR NVUGIB))

\section{Search strategy for ICTRP}

Aspirin AND Bleeding 
Appendix 3 Characteristics of included studies and risk of bias assessment
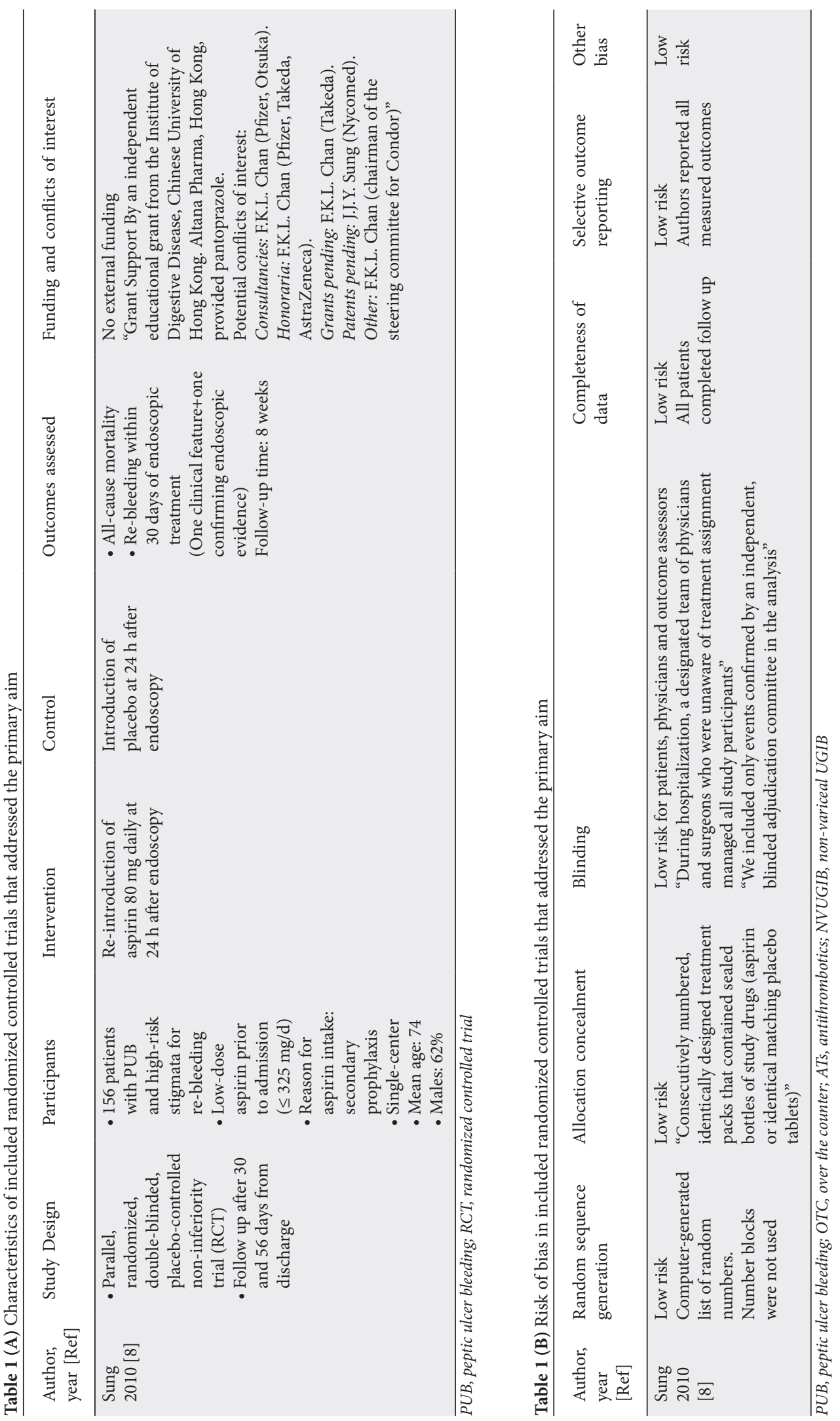


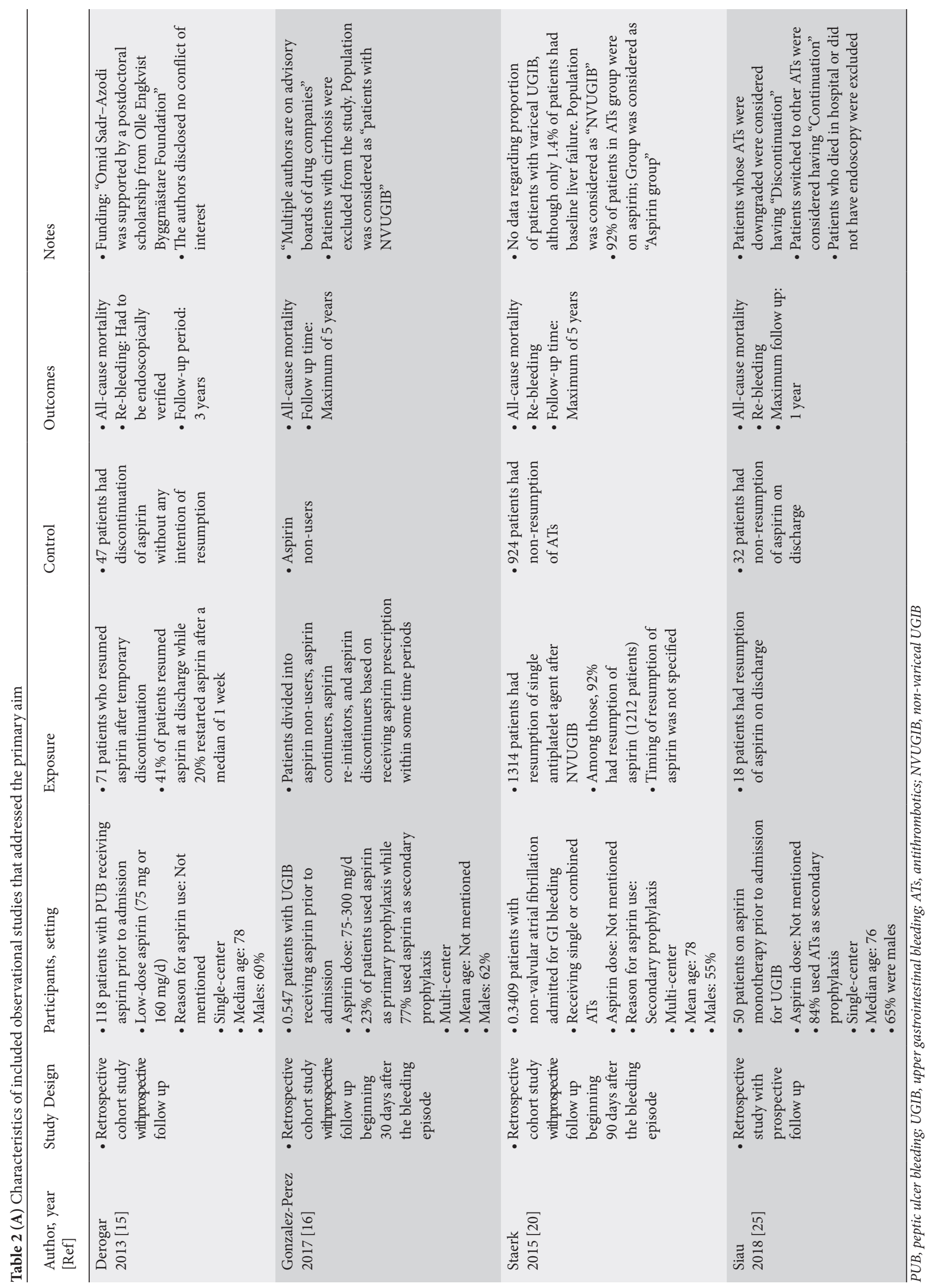


Table 2 (B) Risk of bias in included observational studies that addressed the primary aim

\begin{tabular}{|c|c|c|c|c|c|}
\hline $\begin{array}{l}\text { Author, year } \\
\text { [Ref] }\end{array}$ & $\begin{array}{l}\text { Developing and } \\
\text { applying appropriate } \\
\text { eligibility criteria }\end{array}$ & $\begin{array}{l}\text { Measurement of } \\
\text { exposure }\end{array}$ & $\begin{array}{l}\text { Measurement of } \\
\text { outcome }\end{array}$ & Controlling for confounding & $\begin{array}{l}\text { Completeness } \\
\text { of data }\end{array}$ \\
\hline $\begin{array}{l}\text { Derogar } \\
2013[15]\end{array}$ & $\begin{array}{l}\text { Low risk } \\
\text { Patients with PUB } \\
\text { were retrieved } \\
\text { from a hospital- } \\
\text { administrative } \\
\text { database at a } \\
\text { local hospital in } \\
\text { Stockholm, Sweden }\end{array}$ & $\begin{array}{l}\text { Unclear risk } \\
\text { Based on manual review } \\
\text { of electronic medical } \\
\text { records. } \\
\text { Patients were not } \\
\text { contacted and therefore } \\
\text { actual restart of aspirin } \\
\text { cannot be confirmed. } \\
\text { Also, aspirin is available } \\
\text { OTC and could have } \\
\text { been taken without } \\
\text { documentation }\end{array}$ & $\begin{array}{l}\text { Low risk for } \\
\text { mortality } \\
\text { Information on } \\
\text { death was retrieved } \\
\text { from a trusted } \\
\text { national registry } \\
\text { Unclear risk for } \\
\text { re-bleeding } \\
\text { It was not clear } \\
\text { how patients with } \\
\text { re-bleeding were } \\
\text { identified (was the } \\
\text { same registry used?) }\end{array}$ & $\begin{array}{l}\text { Low risk } \\
\text { Controlling for important } \\
\text { confounders was established }\end{array}$ & $\begin{array}{l}\text { Unclear risk } \\
\text { No mention } \\
\text { of missing } \\
\text { data }\end{array}$ \\
\hline $\begin{array}{l}\text { Gonzalez-Perez } \\
2017 \text { [16] }\end{array}$ & $\begin{array}{l}\text { Low risk } \\
\text { Based on a well } \\
\text { characterized UK } \\
\text { database containing } \\
\text { computerized data } \\
\text { on a large number of } \\
\text { patients }\end{array}$ & $\begin{array}{l}\text { Unclear risk } \\
\text { Based on review of } \\
\text { medical records showing } \\
\text { prescription of aspirin } \\
\text { Patients were not } \\
\text { contacted and therefore } \\
\text { actual restart of aspirin } \\
\text { cannot be confirmed. } \\
\text { Also, aspirin is available } \\
\text { OTC and could have } \\
\text { been taken without } \\
\text { documentation }\end{array}$ & $\begin{array}{l}\text { For mortality: } \\
\text { unclear risk } \\
\text { It is not clear how } \\
\text { mortality was } \\
\text { assessed }\end{array}$ & $\begin{array}{l}\text { High risk } \\
\text { Some patients were assigned } \\
\text { to different groups: Data from } \\
\text { the same patient but from } \\
\text { different points in time have } \\
\text { been assigned to } 2 \text { groups } \\
\text { of interest, depending on } \\
\text { whether patients had started/ } \\
\text { stopped/re-initiated aspirin. } \\
\text { This probably could have } \\
\text { introduced confounding, } \\
\text { given that taking/not taking } \\
\text { aspirin is associated with } \\
\text { different outcomes. }\end{array}$ & $\begin{array}{l}\text { Unclear risk } \\
\text { No mention } \\
\text { of missing } \\
\text { data }\end{array}$ \\
\hline $\begin{array}{l}\text { Staerk } \\
2015[20]\end{array}$ & $\begin{array}{l}\text { High risk } \\
\text { Patients could } \\
\text { have been taking } \\
\text { other ATs prior } \\
\text { to admission for } \\
\text { NVUGIB }\end{array}$ & $\begin{array}{l}\text { Unclear risk } \\
\text { Information about } \\
\text { exposure to aspirin } \\
\text { gathered from a national } \\
\text { prescription registry } \\
\text { Patients were not } \\
\text { contacted and therefore } \\
\text { actual restart of aspirin } \\
\text { cannot be confirmed. } \\
\text { Also, aspirin is OTC and } \\
\text { could have been taken } \\
\text { without documentation }\end{array}$ & $\begin{array}{l}\text { Low risk for } \\
\text { mortality and } \\
\text { re-bleeding } \\
\text { Data for mortality } \\
\text { and re-bleeding } \\
\text { gathered from a } \\
\text { trusted national } \\
\text { database }\end{array}$ & $\begin{array}{l}\text { Low risk } \\
\text { Controlling for important } \\
\text { confounders was established }\end{array}$ & $\begin{array}{l}\text { Unclear risk } \\
\text { It was not } \\
\text { reported } \\
\text { whether } \\
\text { there are } \\
\text { missing data }\end{array}$ \\
\hline Siau 2018 [25] & $\begin{array}{l}\text { Low risk } \\
\text { Criteria were well } \\
\text { defined and applied }\end{array}$ & $\begin{array}{l}\text { Unclear risk } \\
\text { Based on manual review } \\
\text { of electronic medical } \\
\text { records. } \\
\text { Patients were not } \\
\text { contacted and therefore } \\
\text { actual restart of aspirin } \\
\text { cannot be confirmed. } \\
\text { Also, aspirin is available } \\
\text { OTC and could have } \\
\text { been taken without } \\
\text { documentation }\end{array}$ & $\begin{array}{l}\text { Low risk for } \\
\text { mortality and } \\
\text { re-bleeding } \\
\text { Information was } \\
\text { retrieved from a } \\
\text { trusted national } \\
\text { registry }\end{array}$ & $\begin{array}{l}\text { High risk } \\
\text { Controlling for } \\
\text { comorbidities, for severity } \\
\text { of bleeding as well as blood } \\
\text { transfusions was not done }\end{array}$ & $\begin{array}{l}\text { Unclear risk } \\
\text { No reports of } \\
\text { missing data }\end{array}$ \\
\hline
\end{tabular}

PUB, peptic ulcer bleeding; OTC, over the counter; ATs, antithrombotics; NVUGIB, non-variceal UGIB 
Table 3 (A) Characteristics of included observational studies that addressed the secondary aim

\begin{tabular}{|c|c|c|c|c|c|}
\hline $\begin{array}{l}\text { Author, } \\
\text { year [Ref] }\end{array}$ & Study Design & Participants, setting & Exposure & Control & Outcomes \\
\hline $\begin{array}{l}\text { Camus } \\
2016[13]\end{array}$ & $\begin{array}{l}\text { - Prospective } \\
\text { study }\end{array}$ & $\begin{array}{l}\text { - } 0.1264 \text { patients with } \\
\text { severe PUB } \\
\text { - } 2 \text { US tertiary centers } \\
\text { - Mean age: } 61 \\
\text { - Males: } 74 \%\end{array}$ & $\begin{array}{l}\text { - } 468 \text { patients were on } \\
\text { aspirin (not exclusively) } \\
\text { - Aspirin dose: not mentioned } \\
\text { - Reason for aspirin intake: not } \\
\text { mentioned }\end{array}$ & $\begin{array}{l}\text { - } 796 \text { not on aspirin } \\
\text { Patients could have } \\
\text { been receiving } \\
\text { other ATs. }\end{array}$ & $\begin{array}{l}\text { - In-hospital } \\
\text { mortality } \\
\text { - Re-bleeding } \\
\text { - Follow-up time: } \\
30 \text { days }\end{array}$ \\
\hline $\begin{array}{l}\text { Chiu } \\
2009 \text { [14] }\end{array}$ & $\begin{array}{l}\text { - Prospective } \\
\text { study }\end{array}$ & $\begin{array}{l}\text { - } 3220 \text { patients with } \\
\text { PUB requiring } \\
\text { endoscopic therapy } \\
\text { - Single-center } \\
\text { - Mean age: Not } \\
\text { mentioned } \\
\text { - Males: } 67 \%\end{array}$ & $\begin{array}{l}0.336 \text { patients were on } \\
\text { aspirin (Not clear if exclusive) } \\
\text { - Aspirin dose: Not mentioned } \\
\text { - Reason for aspirin intake: Not } \\
\text { mentioned }\end{array}$ & $\begin{array}{l}\text { - } 2884 \text { were not on } \\
\text { aspirin }\end{array}$ & $\begin{array}{l}\text { - In-hospital } \\
\text { mortality }\end{array}$ \\
\hline $\begin{array}{l}\text { Hong } \\
2014[17]\end{array}$ & $\begin{array}{l}\text { - Prospective } \\
\text { study }\end{array}$ & $\begin{array}{l}\text { - } 522 \text { patients with } \\
\text { PUB and successful } \\
\text { hemostasis } \\
\text { - Single-center } \\
\text { - Mean age: } 62 \\
\text { - Males: } 75 \%\end{array}$ & $\begin{array}{l}\text { - } 122 \text { patients were on ATs } \\
0.96 .7 \% \text { were on aspirin }(10 \% \text { on } \\
\text { both aspirin and clopidogrel) } \\
\text { - Aspirin dose: } 100 \mathrm{mg} / \mathrm{d} \\
\text { - Reason for aspirin intake: Not } \\
\text { mentioned }\end{array}$ & $\begin{array}{l}400 \text { patients were } \\
\text { not on ATs }\end{array}$ & $\begin{array}{l}\text { - Re-bleeding } \\
\text { - Follow-up time: } \\
30 \text { days }\end{array}$ \\
\hline $\begin{array}{l}\text { Ishikawa, } \\
2012[18]\end{array}$ & $\begin{array}{l}\text { - Prospective } \\
\text { study }\end{array}$ & $\begin{array}{l}\text { - } 0.305 \text { patients with } \\
\text { severe PUB } \\
\text { - Single-center } \\
\text { - Mean age: } 66 \\
\text { - Males: } 76 \%\end{array}$ & $\begin{array}{l}\text { - } 55 \text { patients were on } \\
\text { aspirin (Not exclusive) } \\
\text { - Aspirin dose: } 80-100 \mathrm{mg} / \mathrm{d} \\
\text { - Reason for aspirin use: Not } \\
\text { mentioned }\end{array}$ & $\begin{array}{l}-156 \text { patients not } \\
\text { taking aspirin nor } \\
\text { NSAIDs }\end{array}$ & $\begin{array}{l}\text { - All-cause in-patient } \\
\text { mortality }\end{array}$ \\
\hline $\begin{array}{l}\text { Liang } \\
2016[19]\end{array}$ & $\begin{array}{l}\text { - Retrospective } \\
\text { study with } \\
\text { prospective } \\
\text { follow up }\end{array}$ & $\begin{array}{l}\text { - } 1229 \text { patients with } \\
\text { PUB }^{1} \text { and endoscopic } \\
\text { hemostasis } \\
\text { - Multi-center (Taiwan) } \\
\text { - Mean age: } 63 \\
\text { - } 35 \% \text { were males } \\
\text { - } 15 \% \text { had CKD }\end{array}$ & $\begin{array}{l}\text { - } 116 \text { patients were on } \\
\text { aspirin (Not exclusive) } \\
\text { - Aspirin dose: not mentioned } \\
\text { - Reason for aspirin intake: not } \\
\text { mentioned }\end{array}$ & $\begin{array}{l}\text { - } 1113 \text { patients not on } \\
\text { aspirin } \\
\text { - Patients could have } \\
\text { been receiving } \\
\text { other ATs }\end{array}$ & $\begin{array}{l}\text { - Mortality } \\
\text { - Re-bleeding } \\
\text { - Follow-up period: } \\
10 \text { years }\end{array}$ \\
\hline $\begin{array}{l}\text { Manguso } \\
2008[21]\end{array}$ & $\begin{array}{l}\text { - Prospective } \\
\text { study }\end{array}$ & $\begin{array}{l}\text { - } 142 \text { patients with } \\
\text { PUB FORREST } 1 \\
\text { - Single-center } \\
\text { - Mean age: } 66 \\
\text { - Males: } 69 \%\end{array}$ & $\begin{array}{l}\text { - } 41 \text { patients were on low-dose } \\
\text { aspirin } \\
\text { - Patients could have been taking } \\
\text { other ATs } \\
\text { - Reason for aspirin use: Not } \\
\text { mentioned }\end{array}$ & $\begin{array}{l}\text { - } 101 \text { not taking } \\
\text { aspirin } \\
\text { - Patients could have } \\
\text { been taking other } \\
\text { ATs }\end{array}$ & $\begin{array}{l}\text { - In-hospital } \\
\text { mortality } \\
\text { - Re-bleeding (within } \\
24 \text { h of endoscopic } \\
\text { hemostasis) }\end{array}$ \\
\hline $\begin{array}{l}\text { Marmo } \\
2010[22]\end{array}$ & $\begin{array}{l}\text { - Prospective } \\
\text { study }\end{array}$ & $\begin{array}{l}\text { - } 1360 \text { patients with } \\
\text { NVUGIB } \\
\text { - Multi-center } \\
\text { - Mean Age: } 68 \\
\text { - Males: } 67 \%\end{array}$ & $\begin{array}{l}\text { - } 248 \text { patients were on aspirin (Not } \\
\text { mentioned if exclusive) } \\
\text { - Aspirin dose: mean of } 100 \mathrm{mg} / \mathrm{d} \\
\text { - Reason for aspirin use: Not } \\
\text { mentioned }\end{array}$ & $\begin{array}{l}\text { - } 1112 \text { patients not } \\
\text { taking aspirin }\end{array}$ & $\begin{array}{l}\text { - All-cause mortality } \\
\text { - Re-bleeding } \\
\text { - Follow-up time: } \\
30 \text { days }\end{array}$ \\
\hline $\begin{array}{l}\text { Mose } \\
2006[23]\end{array}$ & $\begin{array}{l}\text { - Retrospective } \\
\text { study with } \\
\text { prospective } \\
\text { follow up }\end{array}$ & $\begin{array}{l}\text { - } 7204 \text { patients with a } \\
\text { first episode of PUB } \\
\text { - Multi-center } \\
\text { - Median age: } 71 \\
\text { - Males: } 52 \%\end{array}$ & $\begin{array}{l}\text { - } 1029 \text { patients with current use } \\
\text { of low-dose aspirin (at least } \\
1 \text { filled prescription within } \\
100 \text { days prior to bleeding } \\
\text { episode; not exclusive) } \\
\text { - Aspirin dose: } 75-150 \mathrm{mg} / \mathrm{d} \\
\text { - Reason for aspirin use: not } \\
\text { mentioned }\end{array}$ & $\begin{array}{l}\text { - } 5466 \text { patients } \\
\text { who never used } \\
\text { aspirin (not even } \\
\text { previous use) }\end{array}$ & $\begin{array}{l}\text { - All-cause mortality } \\
\text { - Follow-up time: } \\
\text { 30-days }\end{array}$ \\
\hline $\begin{array}{l}\text { Park } \\
2018 \text { [24] }\end{array}$ & $\begin{array}{l}\text { - Prospective } \\
\text { RCT }\end{array}$ & $\begin{array}{l}\text { - } 319 \text { patients with PUB } \\
\text { and high-risk stigmata } \\
\text { for re-bleeding } \\
\text { - Multi-center (7 } \\
\text { hospitals) } \\
\text { - Mean age: } 58 \\
\text { - Males: } 76 \%\end{array}$ & $\begin{array}{l}\text { - } 78 \text { patients were on aspirin (not } \\
\text { clear if exclusively) } \\
\text { - Aspirin dose: not mentioned } \\
\text { - Reason for aspirin use: Not } \\
\text { mentioned }\end{array}$ & $\begin{array}{l}\text { - } 241 \text { patients were } \\
\text { not on aspirin } \\
\text { - Patients could have } \\
\text { been receiving other } \\
\text { ATs }\end{array}$ & $\begin{array}{l}\text { - Re-bleeding } \\
\text { - Follow-up time: } \\
30 \text { days }\end{array}$ \\
\hline
\end{tabular}


Table 3 (B) Risk of bias in included observational studies that addressed the secondary aim

\begin{tabular}{|c|c|c|c|c|c|}
\hline $\begin{array}{l}\text { Author, } \\
\text { year [Ref] }\end{array}$ & $\begin{array}{l}\text { Developing and } \\
\text { applying appropriate } \\
\text { eligibility criteria }\end{array}$ & $\begin{array}{l}\text { Measurement of } \\
\text { exposure }\end{array}$ & $\begin{array}{l}\text { Measurement of } \\
\text { outcome }\end{array}$ & $\begin{array}{l}\text { Controlling for } \\
\text { confounding }\end{array}$ & $\begin{array}{l}\text { Completeness of } \\
\text { data }\end{array}$ \\
\hline $\begin{array}{l}\text { Camus } \\
2016[13]\end{array}$ & $\begin{array}{l}\text { Low risk } \\
\text { Criteria were well } \\
\text { defined and applied. }\end{array}$ & $\begin{array}{l}\text { Low risk } \\
\text { The authors reviewed } \\
\text { the database. } \\
\text { Research coordinator } \\
\text { followed up to } 1 \text { month }\end{array}$ & $\begin{array}{l}\text { Low risk } \\
\text { Mortality and re-bleeding } \\
\text { documented in database } \\
\text { and by interview by a } \\
\text { coordinator }\end{array}$ & $\begin{array}{l}\text { Unclear risk } \\
\text { Controlling for } \\
\text { confounders was } \\
\text { established. } \\
\text { Patients in both groups } \\
\text { could have been } \\
\text { receiving other ATs. }\end{array}$ & $\begin{array}{l}\text { Low risk } \\
\text { Missing data for } \\
\text { aspirin exposure: } \\
0.4 \%\end{array}$ \\
\hline $\begin{array}{l}\text { Chiu } \\
2009 \text { [14] }\end{array}$ & $\begin{array}{l}\text { Low risk } \\
\text { Criteria were well } \\
\text { defined and applied }\end{array}$ & $\begin{array}{l}\text { Low risk } \\
\text { Not mentioned by } \\
\text { authors. Reliable } \\
\text { electronic records in } \\
\text { Hong Kong }\end{array}$ & $\begin{array}{l}\text { Low risk for mortality } \\
\text { Only in-hospital } \\
\text { mortality was evaluated }\end{array}$ & $\begin{array}{l}\text { High risk } \\
\text { Controlling for } \\
\text { confounders was not } \\
\text { established comparing } \\
\text { aspirin users to non-users. }\end{array}$ & $\begin{array}{l}\text { Unclear risk } \\
\text { No report of } \\
\text { missing data }\end{array}$ \\
\hline $\begin{array}{l}\text { Hong } \\
2014[17]\end{array}$ & $\begin{array}{l}\text { Low risk } \\
\text { Criteria were well } \\
\text { defined and applied }\end{array}$ & $\begin{array}{l}\text { Low risk } \\
\text { Medical records were } \\
\text { checked prospectively }\end{array}$ & $\begin{array}{l}\text { Low risk for re-bleeding } \\
\text { Patients were followed } \\
\text { up for more than } 30 \text { days } \\
\text { after hemostasis. }\end{array}$ & $\begin{array}{l}\text { Low risk } \\
\text { Controlling for } \\
\text { important confounders } \\
\text { was established. }\end{array}$ & $\begin{array}{l}\text { Unclear risk } \\
\text { No report of } \\
\text { missing data }\end{array}$ \\
\hline $\begin{array}{l}\text { Ishikawa } \\
2012[18]\end{array}$ & $\begin{array}{l}\text { Low risk } \\
\text { Criteria were well } \\
\text { defined and applied }\end{array}$ & $\begin{array}{l}\text { Low risk } \\
\text { Information retrieved } \\
\text { from electronic medical } \\
\text { records, medication } \\
\text { information documents } \\
\text { and phone calls to other } \\
\text { hospitals. }\end{array}$ & $\begin{array}{l}\text { Low risk for mortality } \\
\text { In-hospital mortality was } \\
\text { evaluated }\end{array}$ & $\begin{array}{l}\text { High risk } \\
\text { There are significant } \\
\text { differences in age and } \\
\text { use of ACs among } \\
\text { aspirin and non-aspirin } \\
\text { groups }\end{array}$ & $\begin{array}{l}\text { Unclear risk } \\
\text { No report of } \\
\text { missing data }\end{array}$ \\
\hline $\begin{array}{l}\text { Liang } \\
2016[19]\end{array}$ & $\begin{array}{l}\text { Unclear risk } \\
\text { No specific } \\
\text { diagnostic criteria } \\
\text { for re-bleeding were } \\
\text { mentioned }\end{array}$ & $\begin{array}{l}\text { Low risk } \\
\text { Information was } \\
\text { retrieved from drug } \\
\text { prescription database }\end{array}$ & $\begin{array}{l}\text { Low risk for mortality } \\
\text { and re-bleeding } \\
\text { Patients' outcomes were } \\
\text { retrieved from national } \\
\text { database }\end{array}$ & $\begin{array}{l}\text { Unclear risk } \\
\text { Controlling for } \\
\text { confounders was } \\
\text { established } \\
\text { Patients in both groups } \\
\text { could have been } \\
\text { receiving other ATs. }\end{array}$ & $\begin{array}{l}\text { Unclear risk } \\
\text { No reports of } \\
\text { missing data }\end{array}$ \\
\hline $\begin{array}{l}\text { Manguso } \\
2008[21]\end{array}$ & $\begin{array}{l}\text { Low risk } \\
\text { Criteria were well } \\
\text { defined and applied. }\end{array}$ & $\begin{array}{l}\text { Unclear risk } \\
\text { There is no information } \\
\text { on how the data } \\
\text { regarding medications } \\
\text { was obtained. }\end{array}$ & $\begin{array}{l}\text { Low risk for in-hospital } \\
\text { mortality } \\
\text { Low risk for } \\
\text { re-bleeding (Inpatient } \\
\text { follow up) }\end{array}$ & $\begin{array}{l}\text { High risk } \\
\text { There was no mention } \\
\text { of controlling for } \\
\text { confounders. }\end{array}$ & $\begin{array}{l}\text { Unclear risk } \\
\text { No report of } \\
\text { missing data }\end{array}$ \\
\hline $\begin{array}{l}\text { Marmo } \\
2010[22]\end{array}$ & $\begin{array}{l}\text { Low risk } \\
\text { Criteria were well } \\
\text { defined and applied. }\end{array}$ & $\begin{array}{l}\text { Unclear risk } \\
\text { There is no information } \\
\text { on how the data } \\
\text { regarding were was } \\
\text { obtained. }\end{array}$ & $\begin{array}{l}\text { Low risk for mortality } \\
\text { and re-bleeding } \\
\text { Clinical outcomes were } \\
\text { tracked during hospital } \\
\text { stay, after discharge to } \\
\text { other health care facility, } \\
\text { and after home discharge }\end{array}$ & $\begin{array}{l}\text { Unclear risk } \\
\text { Controlling for } \\
\text { confounders was } \\
\text { established. } \\
\text { Patients in both groups } \\
\text { could have been } \\
\text { receiving other ATs. }\end{array}$ & $\begin{array}{l}\text { Unclear risk } \\
\text { No report of } \\
\text { missing data }\end{array}$ \\
\hline $\begin{array}{l}\text { Mose } \\
2006 \text { [23] }\end{array}$ & $\begin{array}{l}\text { Low risk } \\
\text { Criteria were well } \\
\text { defined and applied. }\end{array}$ & $\begin{array}{l}\text { Unclear risk } \\
\text { Aspirin intake relied } \\
\text { solely on filled } \\
\text { prescriptions. Patients } \\
\text { were not contacted to } \\
\text { confirm whether they } \\
\text { took aspirin or not. }\end{array}$ & $\begin{array}{l}\text { Low risk } \\
\text { Accurate linkage between } \\
\text { the used registries was } \\
\text { performed. }\end{array}$ & $\begin{array}{l}\text { High risk } \\
\text { Adjustment for other } \\
\text { PUD-associated drugs } \\
\text { was not performed. }\end{array}$ & $\begin{array}{l}\text { Unclear risk } \\
\text { No reports of } \\
\text { missing data }\end{array}$ \\
\hline $\begin{array}{l}\text { Park } \\
2018 \text { [24] }\end{array}$ & $\begin{array}{l}\text { Low risk } \\
\text { Criteria were well } \\
\text { defined and applied. }\end{array}$ & $\begin{array}{l}\text { Unclear risk } \\
\text { There is no information } \\
\text { on how the data } \\
\text { regarding medications } \\
\text { was obtained. }\end{array}$ & $\begin{array}{l}\text { Low risk for re-bleeding } \\
\text { Patients were followed-up } \\
\text { for } 30 \text { days after } \\
\text { endoscopic therapy. }\end{array}$ & $\begin{array}{l}\text { High risk } \\
\text { Only univariate } \\
\text { analysis was conducted. } \\
\text { Adjustment for other } \\
\text { PUD associated drugs } \\
\text { was not performed. }\end{array}$ & $\begin{array}{l}\text { Unclear risk } \\
\text { No reports of } \\
\text { missing data }\end{array}$ \\
\hline
\end{tabular}

